OECD Local Economic and Employment Development (LEED) Papers 2016/01

\title{
Boosting Job Creation in Skive, Denmark
}

\section{Thomas Lynne,} Jonathan Barr,

\section{Michela Meghnagi}

https://dx.doi.org/10.1787/5jm3stcjvfln-en 


\section{Boosting Job Creation in Skive, Denmark}


OECD Working Papers should not be reported as representing the official views of the OECD or of its member countries. The opinions expressed and arguments employed are those of the authors.

Working Papers describe preliminary results or research in progress by the author(s) and are published to stimulate discussion on a broad range of issues on which the OECD works. Comments on Working Papers are welcomed, and may be sent to the Centre for Entrepreneurship, SMEs, Tourism and the Local Economic Development, OECD, 2 rue André-Pascal, 75775 Paris Cedex 16, France.

Authorised for publication by Stefan Kapferer, Director, Centre for Entrepreneurship, SMEs, Tourism and Local Development

You can copy, download or print OECD content for your own use, and you can include excerpts from OECD publications, databases and multimedia products in your own documents, presentations, blogs, websites and teaching materials, provided that suitable acknowledgment of the source and copyright owner is given. All requests for public or commercial use and translation rights should be submitted to rights@oecd.org. Requests for permission to photocopy portions of this material for public or commercial use shall be addressed directly to the Copyright Clearance Center (CCC) at info@copyright.com or the Centre français d'exploitation du droit de copie (CFC) at contact@cfcopies.com. 


\section{ACKNOWLEDGMENTS}

This review has been written by the Local Economic and Employment Development (LEED) Programme of the Organisation for Economic Co-operation and Development (OECD) as part of a project undertaken in co-operation with Skive Kommune This project is part of the OECD LEED programme of work under the leadership of Sylvain Giguère.

The principal authors are Thomas Lynne (Pluss Consultants), Jonathan Barr, and Michela Meghnagi (OECD). The authors would like to thank François Iglesias and other colleagues in the OECD LEED Programme for their assistance with the preparation of this report.

Finally, special thanks are given to the local representatives who participated in the project interviews and roundtables, and provided documentation and comments critical to the production of the report. 


\section{TABLE OF CONTENTS}

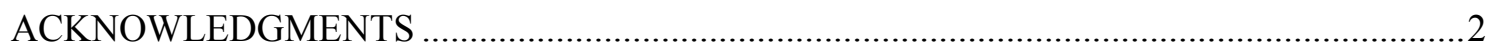

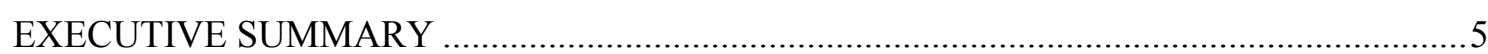

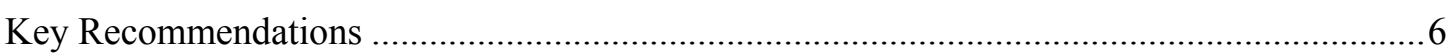

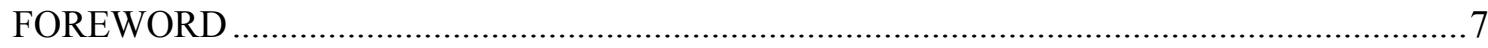

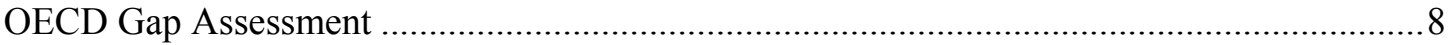

LABOUR MARKET AND ECONOMIC CHARACTERISTICS OF SKIVE ...........................10

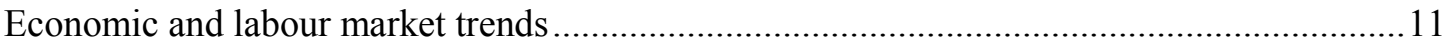

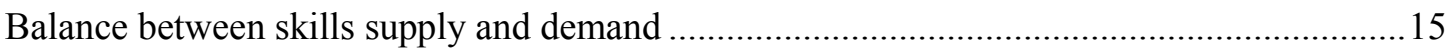

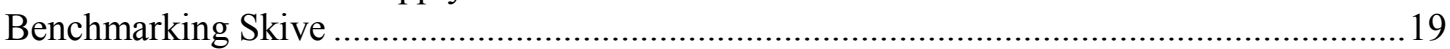

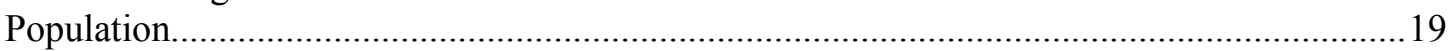

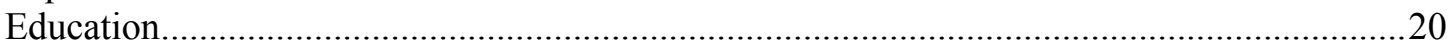

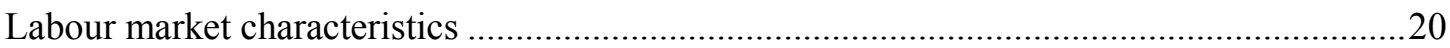

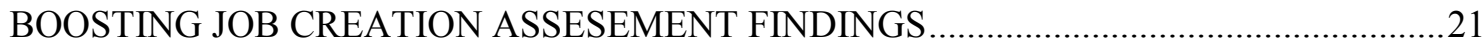

Theme 1: Co-ordination between employment, skills and economic development policies ...23

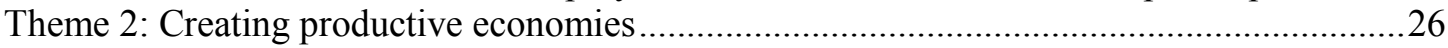

Theme 3: Supporting entrepreneurship and economic development .....................................29

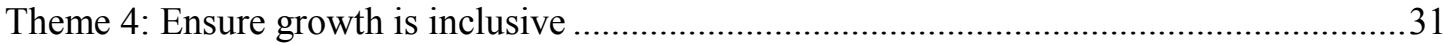

TOWARDS AN ACTION PLAN FOR SKIVE: RECOMMENDATIONS AND

BEST PRACTICES .33

\section{Boxes}

Box 1. Summary of the OECD LEED Boosting Job Creation Methodology .............................

Box 2. Boosting Job Creation: Assessment Tool ................................................................... 8

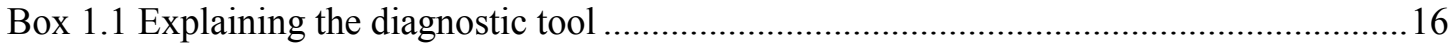

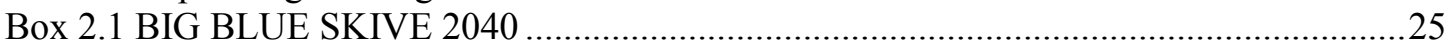

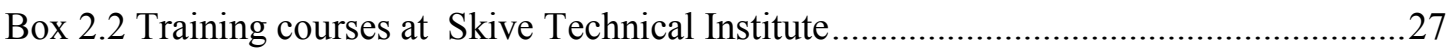

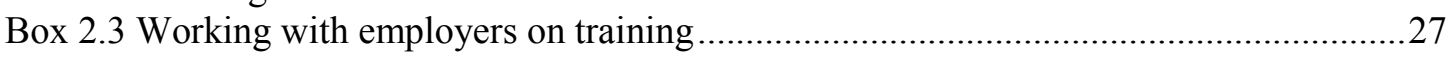

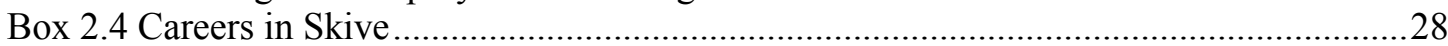

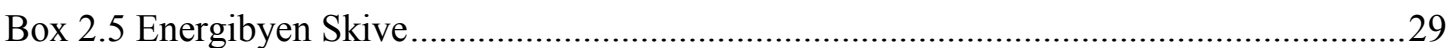

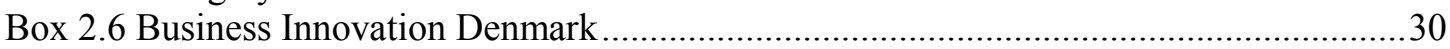

Box 3.1 How to build successful partnerships? ...................................................................

Box 3.2 Establishing a formal partnership to adjust to structural changes - example from Sweden 35

Box 3.2 Workforce Intelligence Network - Michigan, United States ........................................36

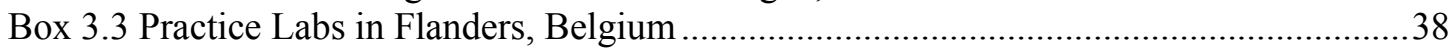

Box 3.4 Supporting Entrepreneurship in Shawinigan, Canada ...............................................39 


\section{EXECUTIVE SUMMARY}

While Denmark performs well compared to many OECD countries, growth remains stagnant compared to the pre-crisis period. Local communities in Denmark, such as Skive face a number of unique labour market and skills challenges, which require measures to promote economic growth and productivity. Creating quality jobs will be a key route towards building new economic advantage and opportunities. Policy makers need to focus on how to best attract investment and people into Skive in addition to how to make better use of the existing skills of the workforce to raise productive capacities.

The OECD Local Economic and Employment Development (LEED) programme has developed a policy innovation project on Boosting Job Creation with the objective of helping local economies develop evidence-based approaches to job creation that are based on broad consensus from local stakeholders. In Skive, the project has built on research and analysis into workforce and skills development issues in the municipality as well as more broadly within Denmark. The project has also extensively engaged a number of local stakeholders in Skive to gather additional intelligence and information about the key policy challenges facing the community and what actions are necessary going forward to stimulate growth and prosperity.

Skive is a medium-sized municipality in Denmark, which has seen significant outward migration of local talents to other communities in the country. While unemployment is lower than the national average, the local labour market is characterised by a deficit of higher level skills and relatively low levels of productivity. Attracting talent into the community should be a critical economic development priority.

There are a range of highly successful programmes and policies, which have been put in place in Skive to activate the unemployed, and raise the overall competitiveness of local sectors. Local government actors have strong informal relationships, which is important for better connecting government programmes and reducing silos that can exist between employment and economic development policies. There is an opportunity to build on the policies that have been put in place to formulate an overall strategy for job creation. This could be achieved through a local board or committee, which is mandated to identify priorities for the community as well as strategic actions which can be taken to attract investment, skills, and new growth opportunities.

As unemployment is low, more efforts will need to be placed on how to boost overall productivity and innovation. This can be achieved by working closer with local employers to raise their production processes and make better use of the existing skills of their workforce. Improving the productive capacity of existing sectors in Skive could raise the overall attractiveness of the community and bring new economic development opportunities.

Skive has benefited from a number of highly skilled immigrants who have chosen to live and work in the community. It is important that government actions focus on how best to efficiently recognise immigrants work experience and ensure that they are well integrated into the labour market. Going forward, immigrants will be a critical source of labour supply for Skive as it seeks new economic development opportunities. 


\section{Key Recommendations}

\section{Co-ordination between employment, skills and economic development policies}

- Strengthen local policy co-operation and co-ordination by fostering partnerships, which can effectively design and implement employment and skills strategies

- Promote and sharing information and data across public sector organisations and coordinate efforts in reaching out to employers to deliver government services in an efficient manner

- Expand capacity building and peer learning activities through partnerships with neighbouring localities in Denmark and internationally

\section{Creating productive economies}

- Expand collaboration between universities, educational institutions, and employers to stimulate innovation and productivity

- Better align the training system with employers by strengthening the skills and competences of VET personnel

\section{Supporting entrepreneurship and economic development}

- Stimulate quality employment through policies which promote the better utilisation of skills in the workplace

- Continue to encourage entrepreneurship opportunities to create more and better jobs

\section{Ensuring growth is inclusive}

- Improve the labour market integration of migrants in order to reduce skills shortages in local industries 


\section{FOREWORD}

The Local Economic and Employment Development Programme of the OECD is engaging with local economies to help them prepare evidence-based approaches to job creation that are based on broad consensus from local stakeholders. The OECD brings over three decades of experience in this area to the task, having analysed and accumulated lessons from successful approaches to local job creation worldwide. Localities are helped to identify the elements that need strengthening in their existing strategies. Realistic proposals for change are considered, bearing in mind national and local policy contexts. This work is underpinned by concrete examples of methods used in places facing similar challenges, both within each country and elsewhere.

The key stages of each review are summarised in Box 1.

\section{Box 1. Summary of the OECD LEED Boosting Job Creation Methodology}

- A gap assessment: to establish strengths and weaknesses of the local labour market, and the local policy context using key indicators and benchmarks established by the OECD.

- A workshop to discuss analysis/results and their implications for local actions: in this roundtable local stakeholders are helped to identify key opportunities and challenges associated with the local context for local job creation, building on the gap assessment. The OECD brings evidence and best practices emerging from the experience of other areas facing similar challenges.

- An action plan and practical suggestions for its implementation: building on the discussions at the workshop an action plan is developed in consultation with all stakeholders involved. This sets out key objectives and practical steps to undertake in relation with the obstacles identified during the discussions. Mechanisms for ongoing support from the OECD will also be identified where necessary and/or appropriate.

High unemployment remains a pressing concern for many localities and regions following the economic crisis. In many places it will take time before employment and productivity fully recovers. This is obviously a concern for national governments. But national policies do not dictate a community's future. Municipalities, districts, provinces and regions have an opportunity to speed up change and seize new economic opportunities. With the right strategies and implementation plans, the fortunes of local businesses, jobs and people can be significantly changed for the better.

Engineering successful strategies for job creation is not an easy task, and requires putting many different parts of the 'policy jigsaw' into place. Local and regional authorities must have the capacity to act quickly and decisively on the strengths and weaknesses of their local economy, building on local comparative advantage, while remaining open to diversification and change. And they must show a commitment to engaging all local stakeholders in order to build the critical capacities and resources required to generate real and long-term growth. 
In response to this issue, the OECD LEED Programme has developed a set of thematic areas on which local stakeholders and employment and training agencies can focus to build sustainable growth at the local level. These include:

1. Co-ordination between employment, skills, and economic development policies: As we move towards a knowledge-based economy, a skilled workforce is becoming increasingly important to firms' decisions to locate and/or expand in a local area. This makes it essential to align labour market, training and economic development policy locally. Businesses need to be able to source appropriate skills as they expand and grow.

2. Creating productive economies - avoiding the low skills trap: There are considerable local variation in employer demand for skills. Some areas are stuck in a "low skills equilibrium", where local employers offer low-skilled jobs and operate in low-cost markets, so there are few high quality jobs available. In such regions, technical assistance, management training, and embedding skills policies in broader mechanisms for business support can encourage demand for higher levels of skills.

3. Supporting entrepreneurship and economic development: Net job creation is typically led by a small number of "high growth firms" which are strongly dependent on their local economic context. Policy makers can support such high growth by developing local entrepreneurial ecosystems and targeted support such as business accelerators. Partnerships between universities, vocational training institutions, local economic agencies and firms can help to promote knowledge-sharing and hence innovation and diversification - building new jobs on the back of old ones.

4. Ensuring growth is inclusive: Some disadvantaged groups, such as young people not in education, employment, or training (NEET), can face multifaceted barriers to employment, requiring targeted support to ensure that no individuals or communities are left behind. Using evidence-based approaches is critical to addressing both the immediate barriers to employment and the root causes of long-term labour market exclusion.

\section{OECD Gap Assessment}

As part of the project, the LEED Programme has drawn on its previous research to develop a set of best practice priorities in each area, which is used to assess local practice through a gap assessment tool (see Box 2). The dashboard enables local policy-makers to gain a stronger overview of the strengths and weaknesses of the current policy framework, whilst better prioritising future actions and resources. A value between 1 (low) to 5 (high) is assigned to each indicator corresponding to the relative strengths and weaknesses of local policy approaches based on best practices in other OECD countries.

\section{Box 2. Boosting Job Creation: Assessment Tool}

1. Co-ordination between employment, skills and economic development policies -- Better aligning policies and programmes to local economic development

1.1. Degree of flexibility in designing and implementing policies and initiatives

1.2. Degree of integration between employment, skills and economic development

1.3. Degree of utilisation of local data in evidence-based policy making

2. Creating productive economies -- Adding value through skills and avoiding the low skills trap 
2.1. Extent to which training is available in a broad range of sectors, flexible and accommodating the needs of workers and unemployed individuals

2.2. Degree of employer engagement in orienting skills development to demand and extent to which training meets business needs

2.3. Degree of support to employers/SMEs in maximising skills utilization, improving work organisation, human resource management, workforce planning and skills development

3. Supporting entrepreneurship and economic development -- Targeting policy to local employment sectors and investing in quality jobs

3.1. Extent to which programmes and services are adapted to local business demographics and profiles, addressing SME needs

3.2. Degree of access to finance by SMEs

3.3. Extent to which SMEs are helped to benefit from internationalisation opportunities

3.4. Degree of development of local entrepreneurial/innovation ecosystems, and extent of knowledge-sharing

4. Ensure growth is inclusive - seizing economic and skills development opportunities to strengthen the vulnerable in the labour market

4.1. Extent to which effective policies are in place to support the labour market integration of disadvantaged groups and degree of flexibility in adapting programmes to different target groups

4.2. Extent to which there are evidence-based tools used to measure disadvantage on the labour market and support multi-stakeholder approaches to tackling disadvantage

\section{The approach for Skive}

This study has looked at the range of institutions and bodies involved in workforce and skills development in Skive, Denmark. Between May-June 2015, a number of interviews were undertaken with key stakeholders across employment, training, and economic policy portfolios in Skive. The purpose of the interviews was to understand the key challenges facing the region, the main institutions involved in employment and skills policies as well as to identify promising local practices to boost job creation.

In June 2015, a roundtable was held to bring together key stakeholders in the community to discuss the preliminary findings of the study and agree on potential actions and policies, which could be introduced to achieve better outcomes. 


\section{Section 1}

\section{LABOUR MARKET AND ECONOMIC CHARACTERISTICS OF SKIVE}

Skive municipality faces a number of labour market challenges and opportunities. Recent trends have resulted in negative outward migration and population decline. Immigrants who possess higher levels of skills have partially mitigated this loss of supply within the municipality.

After a peak during the crisis, unemployment has gradually decreased in Skive and compares favourably with the rest of Denmark. The duration of unemployment is also lower than in the rest of the country and there is a relative high share of unemployed people who participate in guidance and training activities suggesting that the municipality is active in helping people get back into labour market.

When comparing the supply and demand of skills, Skive is in a low-skills equilibrium, which suggests that there is a prevalence of poor quality jobs in the municipality. This means that policies will need to focus on boosting the overall supply of skills, while also seeking to boost the productive capacity of existing jobs in the municipality to further attract investment and economic development opportunities. 


\section{Economic and labour market trends}

The municipality of Skive is one of the 98 Danish municipalities ${ }^{1}$. It is located in the Central Denmark Region (Region Midtjylland) and belongs to the province of Western Jutland (Vestjylland). With a population of 46600 people, Skive is the $44^{\text {th }}$ largest municipality in the country. Nearly half of the population is situated in the main town of the municipality, also called Skive.

The OECD's recent Economic Survey of Denmark notes that the Danish economy has grown hardly at all since 2010 (OECD, 2014a). In the wake of the global economic crisis and the burst of the housing market bubble, there has been a significant slowdown in overall productivity, which has been a further drag on growth. This national trend aligns with the overall trend in the Midtjylland region. Data for Skive, which is part of Vestjylland Province, shows that a stronger decrease of GDP during the crisis and a more pronounced improvement in the after crisis period.

Figure 1.1 Growth has been stagnant since the global economic crisis

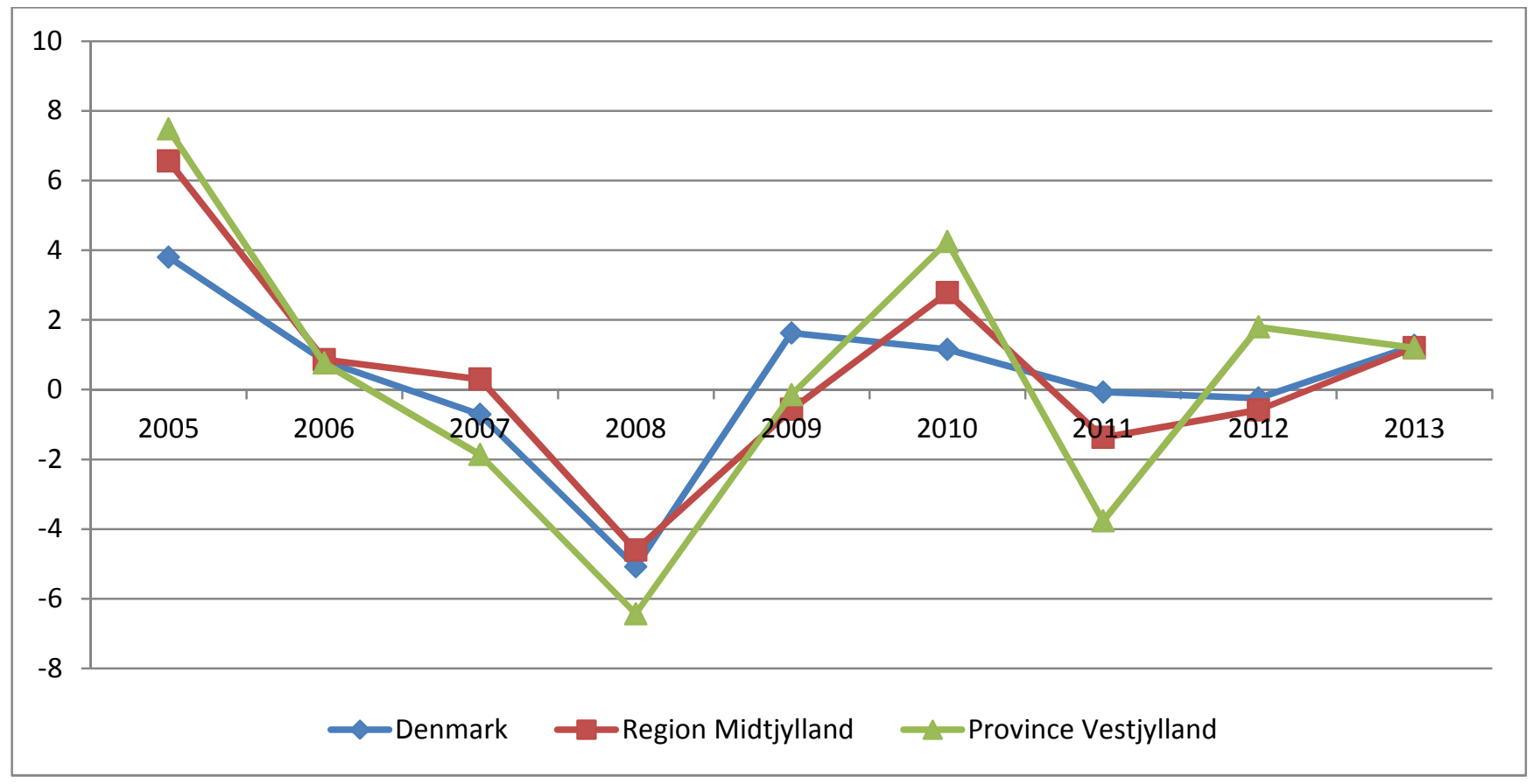

In recent years, the population of Skive municipality has shown a slow decline caused mainly by negative internal migration. This trend has been somewhat mitigated by increasing international migration (see Figure 1.2). Data shows that the share of immigrants as a percentage of the total population in Skive went from $4.5 \%$ in 2008 to $5.6 \%$ in the $2^{\text {nd }}$ quarter of 2015 .

\footnotetext{
${ }^{1}$ Not including the archipelago of Christiansø (also known as Ertholmene)
} 
Figure 1.2 Population trends in Skive, 2006-14

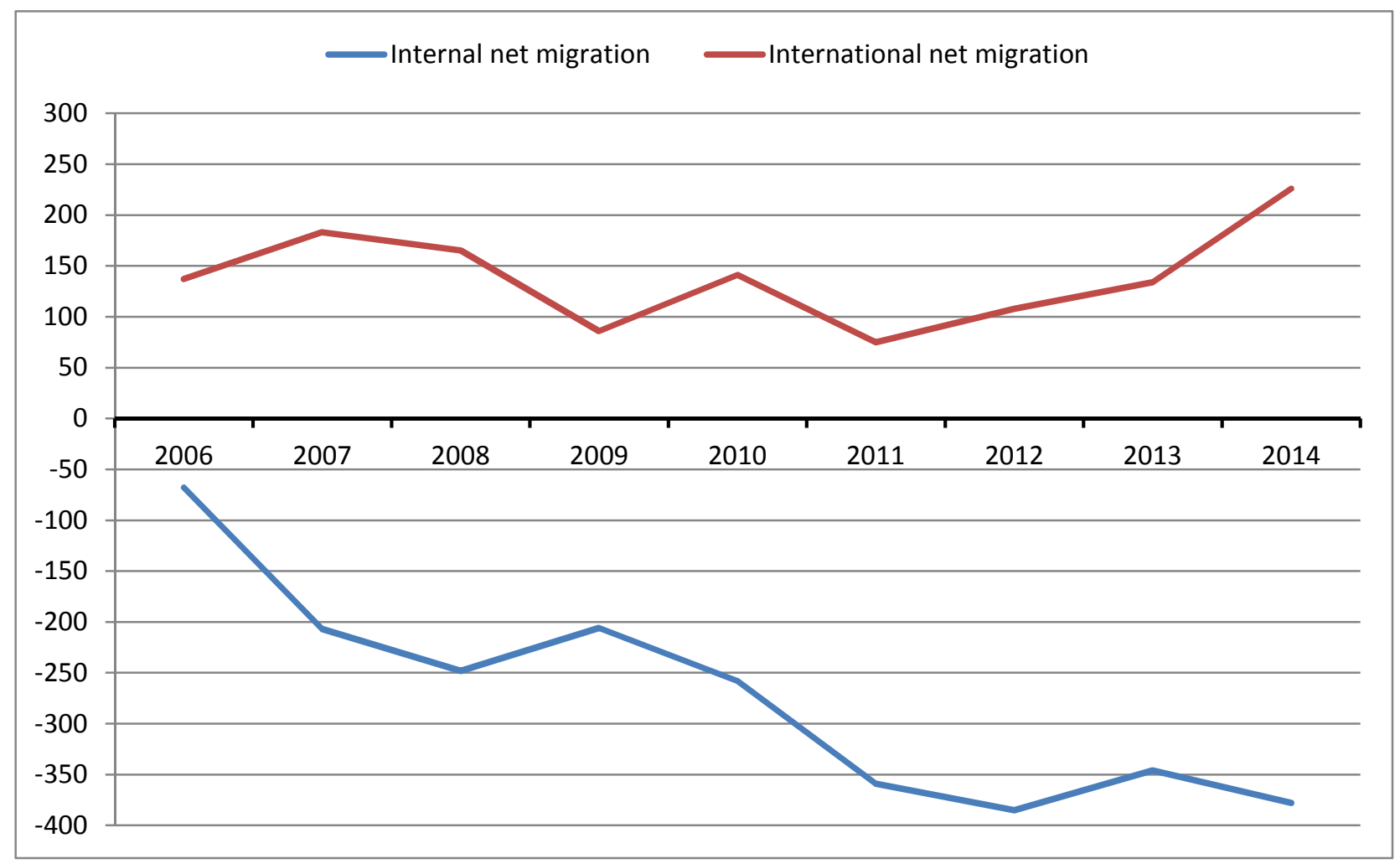

Source: Statistics Denmark

When looking at skills, Denmark performs at about the OECD average. Between 2008-2012, the proportion of Danes with a tertiary education grew both among the young (aged 25-34) and older adults (aged 55-64), from 36\% to $40 \%$ and from $26 \%$ to $29 \%$ respectively (OECD, 2014a). The OECD's recent Economic Survey of Denmark showed that the share of 30-34 year olds who had completed at least secondary education is at the OECD average, but much below that of Finland and other countries with well-developed vocational education and training, systems, such as Germany, Austria, and Switzerland (OECD, 2014b)

Skills levels in Skive are lower than in the rest of Denmark. In particular, more than a third of the population has basic education $(34.6 \%)$ and $38.7 \%$ has vocational education. Interestingly only $3.3 \%$ of the population has a bachelor degree or above versus $10.3 \%$ when looking at the national average for Denmark. Immigrants in Skive are relatively well qualified compared to the population with Danish origins. Immigrants have lower shares of basic education (30\%) and highest shares of secondary and tertiary education $(9.2 \%$ and $7.9 \%$ respectively). 
Figure 1.3 Comparing the skills levels in Skive to Denmark, 2014

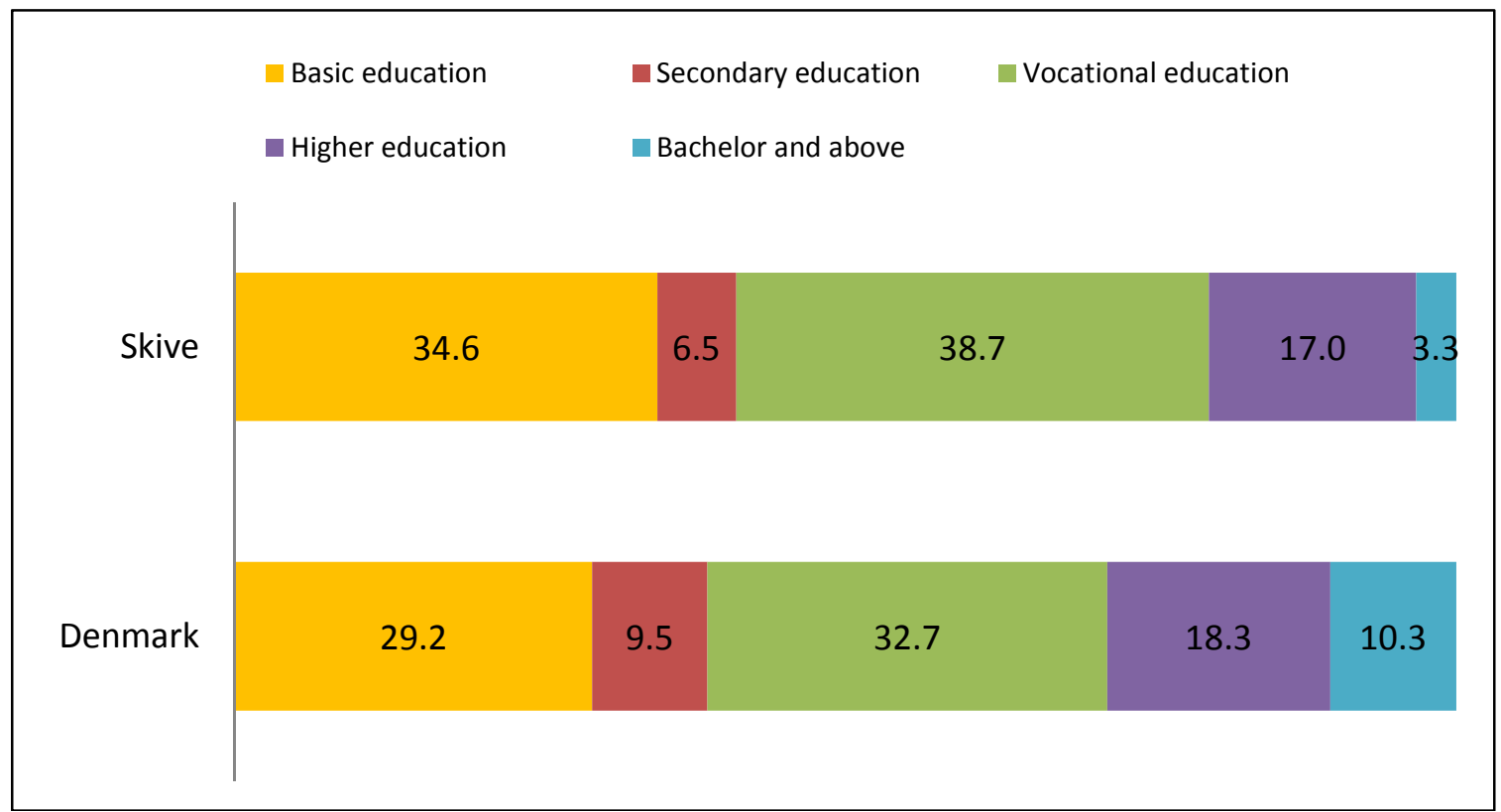

Source: Statistics Denmark

Figure 1.4 Skills levels of immigrants in Skive, 2014

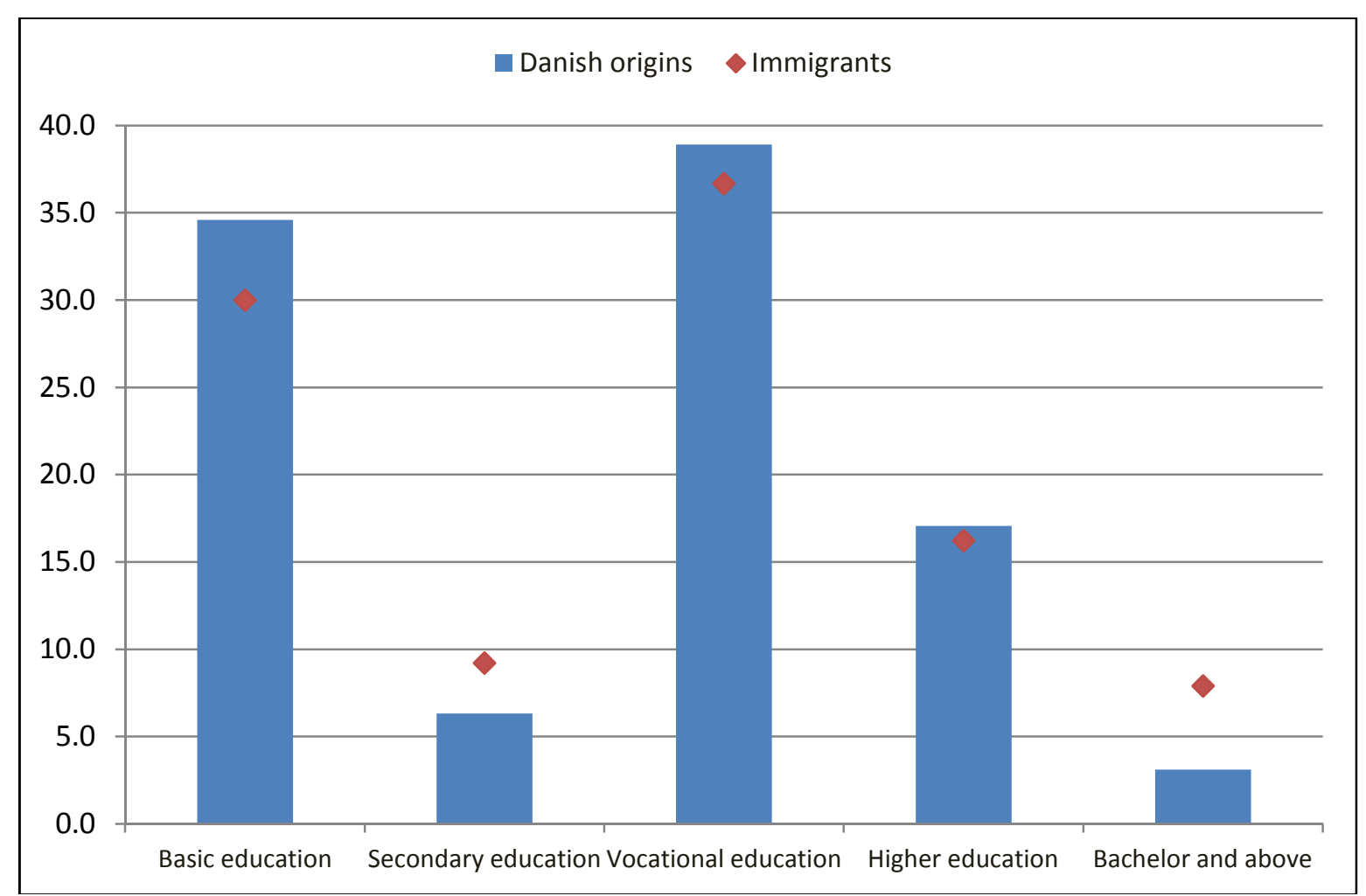

Source: Statistics Denmark 


\section{Labour market in Skive}

Similar to the rest of the province, the public sector is the main employer in Skive municipality with $33.7 \%$ of the workforce working in the public administration, education and health sectors. Within this sector, residential care activities provide almost half of the jobs. The second largest employment provider is the trade, transportation and accommodation and food services sector with slightly less than $20 \%$ of employment, followed by the manufacturing sector (17.9\%) - see Figure 1.5 below. Manufacturing in Skive is particularly developed in electronic components (18\%), basic metals and fabricated metal products (17\%), furniture as well as wood and paper products and printing (both 15\%).

Compared to the average employment in manufacturing in Denmark (10\%), this figure highlights the importance of this sector in Skive. This is true also for Western Jutland where manufacturing is the most significant economic sector producing more than one third of the total output of the province. The share of self-employment in Skive (at 8.3\% in 2013) is higher than the average regional and national level. Selfemployment is particularly strong in the agriculture, forestry and fishery sectors (32\%), followed by wholesale and retail trade industries (12\%) and construction (9\%).

Figure 1.5 Employment by economic sector, Skive, 2013

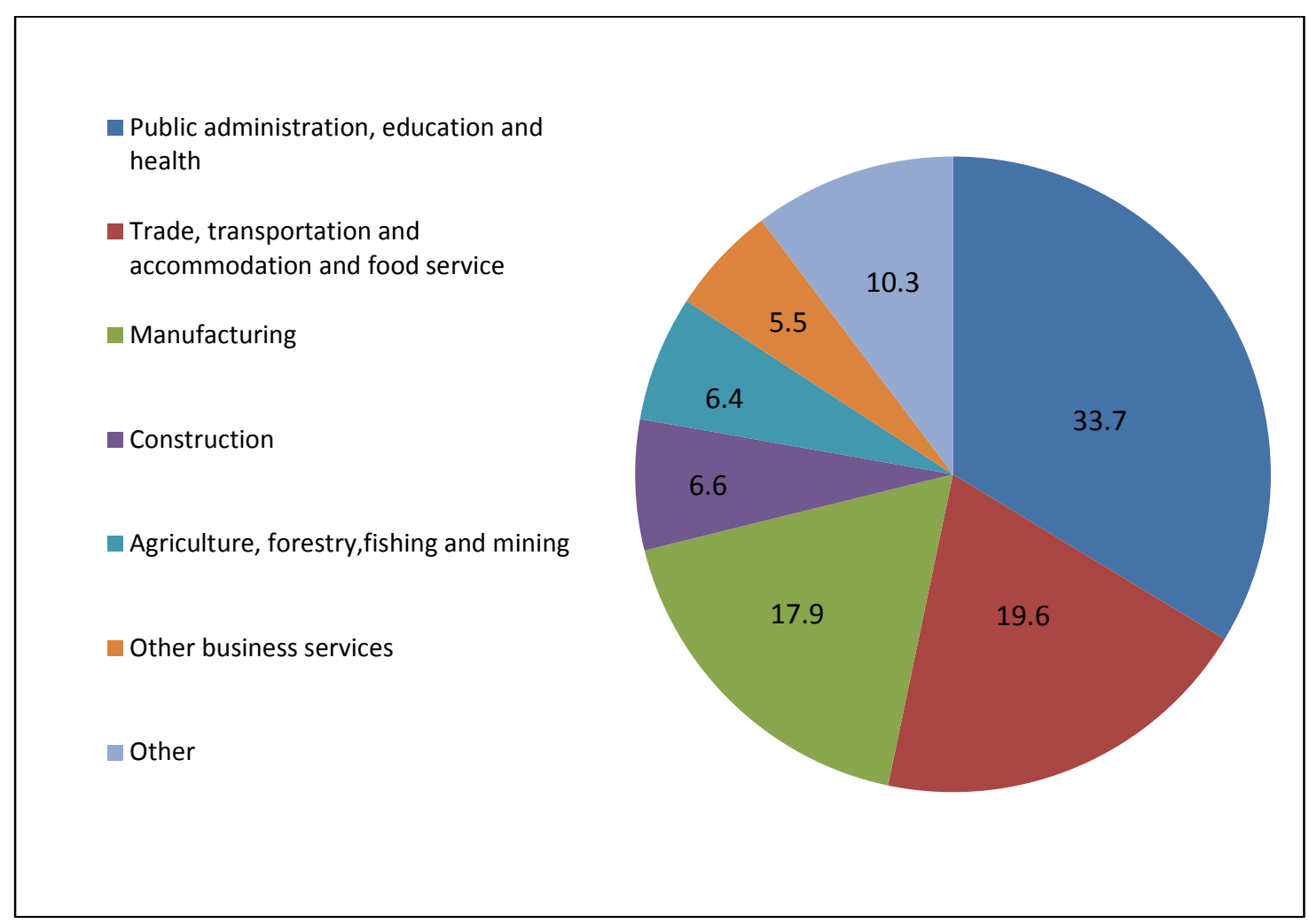

Source: Statistics Denmark

The unemployment rate in Skive increased significantly between the beginning of 2008 and the end of 2010 showing a peak at $7.6 \%$ at the end of 2009 . Since then, unemployment has been decreasing with the latest data available showing unemployment at 3.3\%, significantly lower than the Danish average. It is worth mentioning that the decrease of unemployment is also a consequence of the decrease in the labour 
market participation rate and the increasing share of people out of the labour market (discouraged workers).

Figure 1.6 Unemployment trends in Denmark and Skive, 2007-15

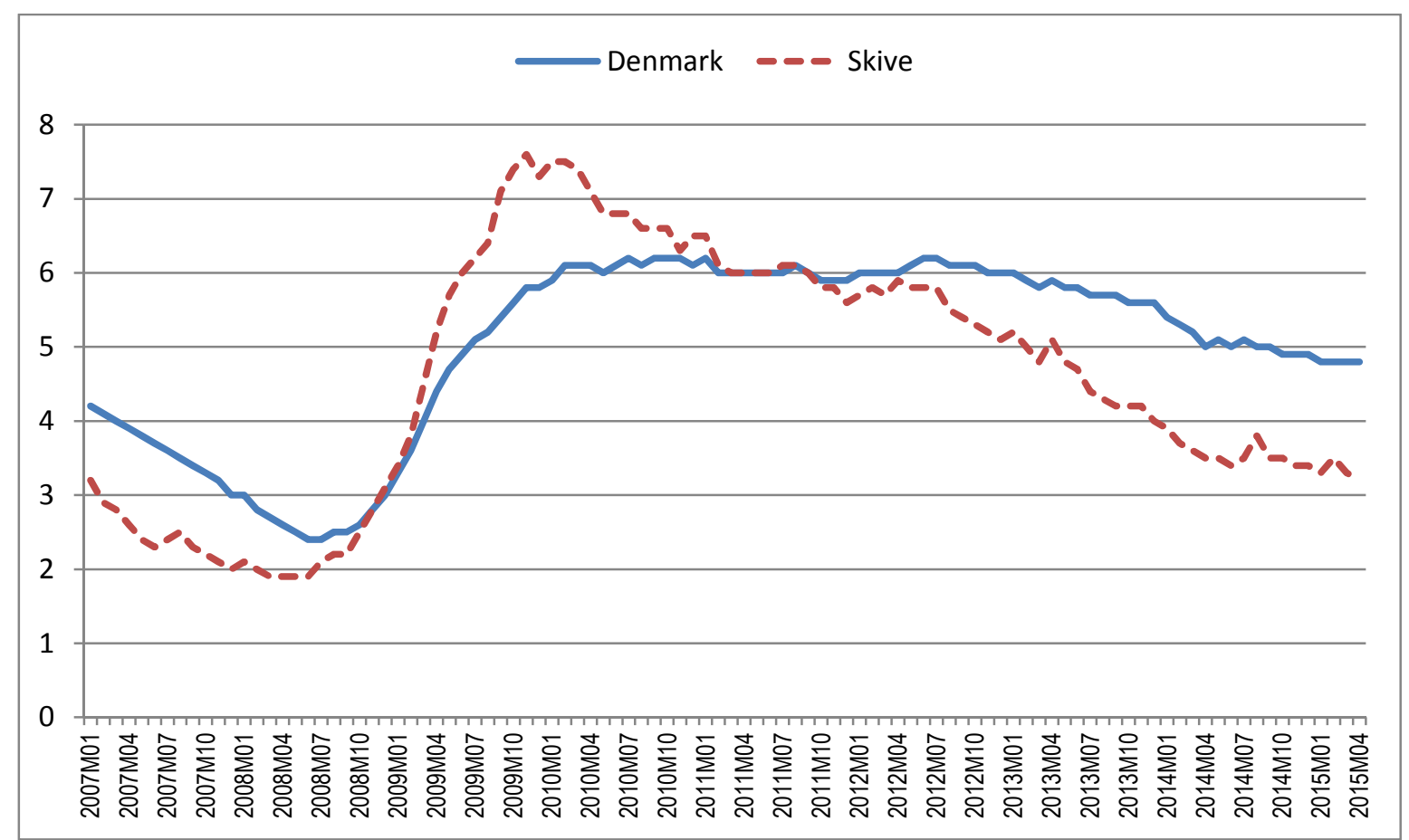

Source: Statistics Denmark

The average duration of unemployment, according to the administrative data, is also lower than in the rest of the country - 13 weeks in Skive compared to a national average of 17 weeks in Denmark. In Skive, managers, employees from finance, insurance, police, defence, transport sectors and teachers have longer periods of unemployment. Interestingly both in Denmark and in Skive, youth unemployment is lower than total unemployment and the female unemployment rate is close to total unemployment.

\section{Benefits recipients}

In Denmark, the unemployment insurance system is voluntary and only unemployed who are registered with an unemployment insurance fund are entitled to receive unemployment benefits. Those who are not registered can receive social benefits which are administered by local authorities. Social benefits are given either to people who look for a job or people who are not able to work (e.g. long-term sick). After a peak in 2009-2010, the share of people receiving unemployment benefits in Skive has decreased and reached levels lower than during the pre-crisis period.

The share of registered unemployed receiving guidance and activities to upgrade their skills has significantly increased in Skive, showing since 2010 levels much higher than the rest of Denmark. Among the different forms of subsidised employment, Skive shows particularly high levels of employment subject to wage subsidies (only for public sector companies) and job rotation.

\section{Balance between skills supply and demand}

The OECD LEED Programme has developed a statistical tool to understand the balance between skills supply and demand within local labour markets (Froy, Giguère and Meghnagi, 2012). In the Danish 
context, this tool can help to provide policy makers with an understanding of skills mismatches, which may occur at the sub-national level. It can inform place-based policy approaches at the local level.

Figure 1.7 Understanding the relationship between skills supply and demand

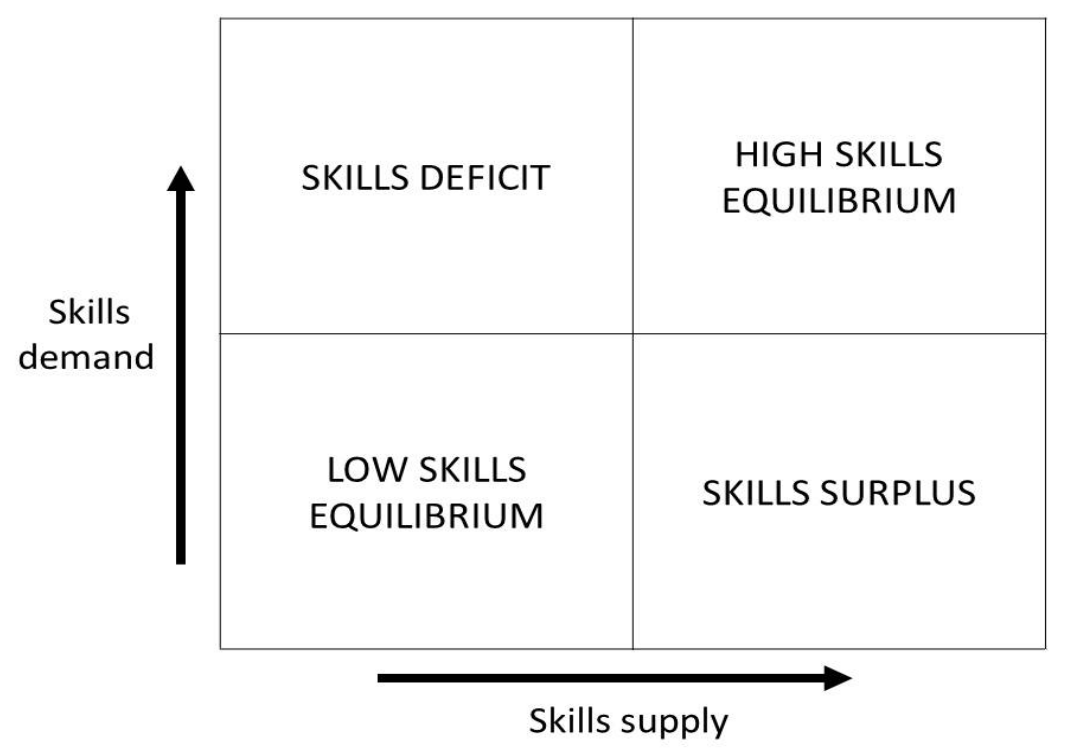

Source: Froy, F., S. Giguère and A. Hofer(eds.) (2009), Designing Local Skills Strategies, http://dx.doi.org/10.1787/9789264066649-en adapted from Green (2003).

Looking at the figure above, in the top-left corner (skills deficit), demand for high skills is met by a supply of low skills, a situation that results in reported skills gaps and shortages. In the top-right corner, demand for high skills is met by an equal supply of high skills resulting in a high-skill equilibrium. This is the most desired destination of all high performing local economies. At the bottom-left corner the demand for low skills is met by a supply of low skills resulting in a low-skill equilibrium. The challenge facing policymakers is to get the economy moving in a north-easterly direction towards the top-right corner. Lastly, in the bottom-right corner, demand for low skills is met by a supply of high skills resulting in an economy where what high skills are available are not utilised. This leads to the out migration of talent, underemployment, skill under-utilisation, and attrition of human capital, all of which signal missed opportunities for creating prosperity.

\section{Box 1.1 Explaining the diagnostic tool}

The analysis is carried out at Territorial Level 3 regions (regions with populations ranging between 150 000-800 000). The supply of skills was measured by the percentage of the population with post-secondary education. The demand for skills was measured by the percentage of the population employed in medium-high skilled occupations. Regions are also classified in relation to the average state unemployment rate. The indices are standardised using the inter-decile method and are compared with the national median. Further explanations on the methodology can be found in Froy, Giguère and Meghnagi, 2012.

Source: Froy, F., S. Giguère and M. Meghnagi (2012), "Skills for Competitiveness: A Synthesis Report", OECD Local Economic and Employment Development (LEED) Working Papers, No. 2012/09, OECD Publishing. doi: 10.1787/5k98xwskmvr6-en

This typology has been applied to both the regions and provinces of Denmark. The map below shows the skills balance at the regional level with Skive highlighted with a red star. The capital region is in the high-skills equilibrium, showing relatively high levels of both skills supply and demand. The central and 
southern regions are in a situation of skills surplus (where the supply of skills is greater than the demand for skills). The Zealand and the Northern regions are in the low skills equilibrium, where low skills supply is matched by low demand of skills. These regions are more likely to have a prevalence of poor quality jobs.

Figure 1.8 Skills supply and demand, Danish regions, 2011

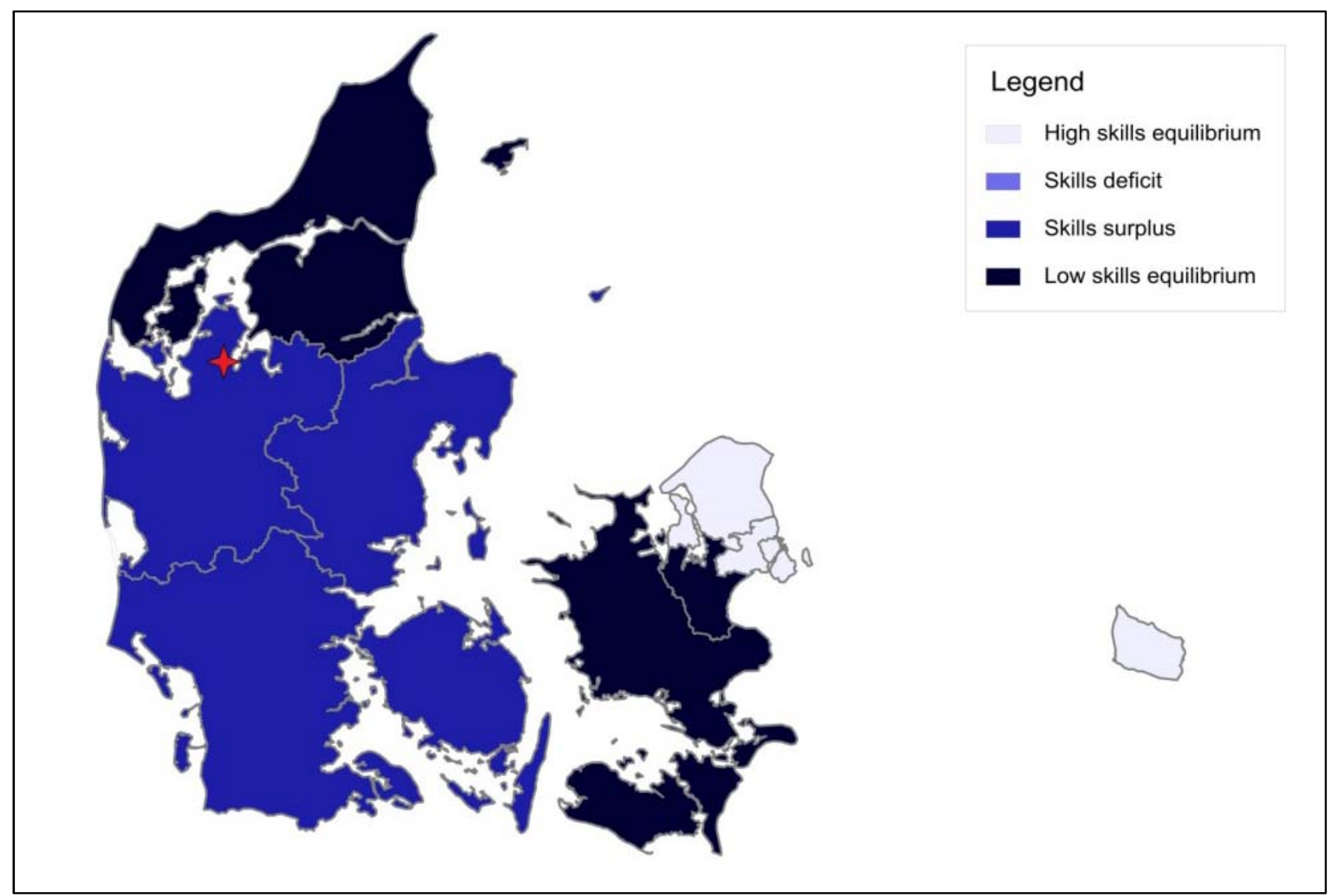

Source: LEED calculations based on Statistics Denmark data

In order to have a better understanding of the skills balance in Skive, the same analysis was conducted also by looking at provincial ${ }^{2}$ level data. In the figure below, the province of Western Jutland where Skive is located falls into the low skills equilibrium but very close to the skills deficit quadrant. This result suggests that skilled people leave Skive to find more qualified jobs in other parts of the country and that employers do not have enough skilled workers in the municipality to fill the available job vacancies.

\footnotetext{
${ }^{2}$ The province of Bornholm is excluded from the analysis due to the low number of observations.
} 
Figure 1.9 Skills supply and demand, Danish provinces, 2013

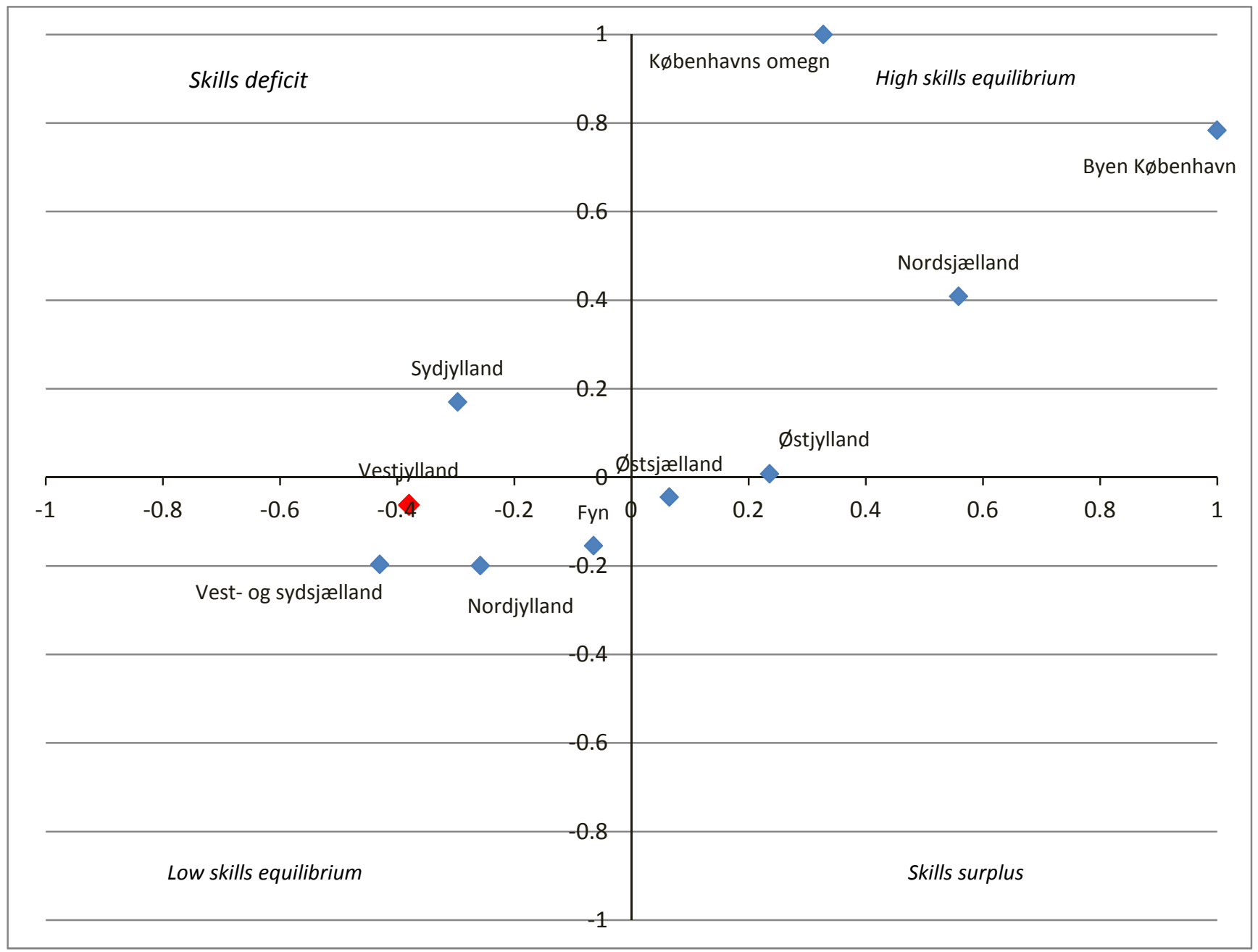

Source: LEED calculations based on Statistics Denmark data 


\section{Benchmarking Skive}

In order to identify strengths and weaknesses of Skive when compared to similar localities in Denmark, four municipalities, one from each region, have been identified for benchmarking analysis. The map below shows the benchmarking places.

Figure 1.10 Benchmarking the skills supply and demand of Skive, 2013

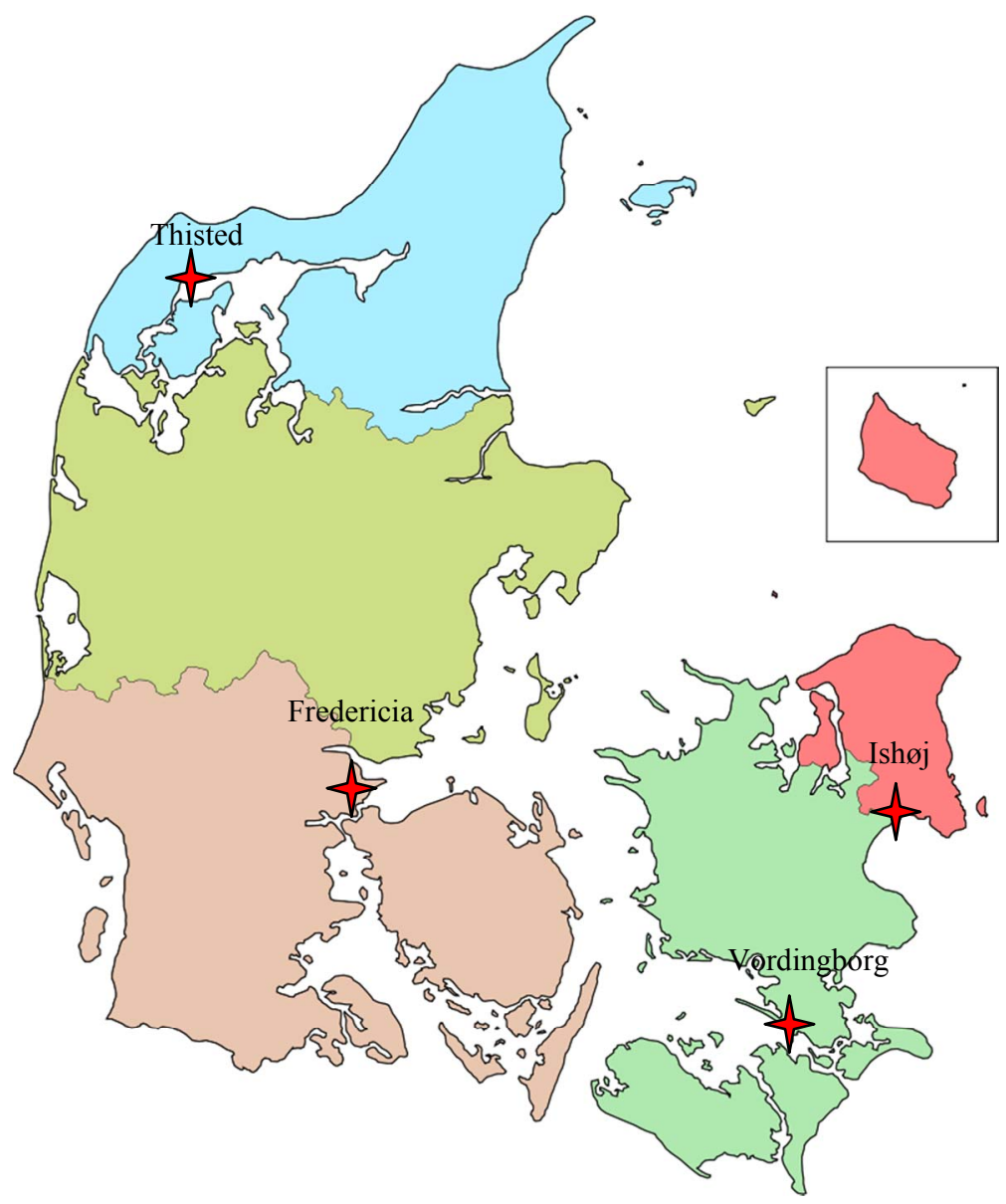

\section{Population}

All the benchmarking municipalities except Ishoj have a population that ranges between 45000 and 50 000. Ishoj is nearly half of the size of the other benchmarks and it is known for its very high share of resident migrants (more than a third of the population) and the main town of the municipality, which is also called Ishoj, hosted the first big housing project of the country as part of a broader integration plan.

All the benchmarking municipalities have positive international migration flows but they significantly differ in terms of internal migration with Skive and Thisted having negative net migration. Only Fredericia and Ishoj showed a population increase between 2009 and 2014. 


\section{Education}

All municipalities have a high level of people having basic education, ranging from $33.5 \%$ in Fredericia to $39 \%$ in Ishoj. The latter has nearly half of the population $(48.6 \%)$ with basic and secondary education. This figure is ten percentage points higher than the other municipalities and Denmark as a whole. Interestingly Ishoj also has a slightly higher share of the population with bachelor degree or above.

Vordingborg, Fredericia and Skive have the highest share of people with higher education (around $17 \%$ ), which is still lower than the Danish average of $18.3 \%$. Skive and Thisted show a very similar educational attainment structure with around $40 \%$ of people having vocational education and less than $3.5 \%$ having bachelor degree or above.

\section{Labour market characteristics}

All benchmarking municipalities are characterised by significant shares of people employed in the public sector, including public administration, defence and compulsory social security, education, human health activities and residential care. Similar to Skive, residential care is the main public sector employer for all municipalities, with Ishoj having an education sector that is particularly developed.

Skive and Thisted also have stronger manufacturing sectors than in the other municipalities. However the former is specialised in the production of electronic components whereas the latter produces mainly food products, beverages and tobacco. Ishoj is characterised by employment in construction $(11 \%)$ and wholesale and retail trade (24\%). Fredericia has high employment in the transportation sector while Vordingborg does not seem to have another strong employment provider in addition to the public sector.

At the beginning of 2015, Ishoj was the municipality with the highest unemployment rate at $9.6 \%$. Youth unemployment was also higher than in the other benchmarking municipalities in recent years but it has started decreasing in 2014 and it was close to the other localities at the beginning of 2015. Similar to the rest of Denmark, gender differences in unemployment are not strong in all benchmarking municipalities except in Ishoj.

\section{Conclusion}

Skive municipality has lost population in recent years, mainly because of internal out-migration. International migration flows have increased over time, compensating for the loss of labour supply. Overall the levels of educational attainment is lower than in the rest of the country but immigrants in Skive, who represent slightly less than $6 \%$ of the population, have relatively high skills and represent a resource of supply for the municipality.

Skive is a low skills equilibrium, where a low supply of skills is matched by a low demand, but also shows characteristics similar to skills deficit areas where employers struggle to find the right skills to fill the vacancies in the area. As the model used for the analysis looks at medium and high skilled occupations, this result suggests that efforts need to be taken to attract more qualified workers into the community.

The services provided for the unemployed seem to be efficient as the duration of unemployment is lower than in the rest of the country and guidance and training for unemployed is relatively common suggesting that there is a willingness to help people get back into the labour market. In comparison with the benchmarking places, Skive looks similar to Thisted in terms of educational attainment and employment characteristics but the unemployment rate was higher at the end of 2015. 


\section{Section 2}

\section{BOOSTING JOB CREATION ASSESEMENT FINDINGS}

This section highlights findings from the boosting job creation dashboard in Skive. The findings are discussed through the four thematic areas of the review: 1) co-ordination between employment, skills and economic development policies; 2) creating productive economies; 3) Supporting entrepreneurship and economic development; and 4) ensuring growth is inclusive. 


\section{Results from the assessment tool}

This section of the report presents the key findings from the in-depth fieldwork undertaken in Skive. Figure 2.1 shows the overall results from the boosting job creation dashboard across the four thematic areas of the review. In this chapter, each of the priority areas within each theme is presented and discussed sequentially, accompanied by an explanation of the results.

The overall assessment points to a robust range of programmes and policies to support job creation and employment. This chapter highlights successful initiatives that have been introduced in Skive as well as organisations that are doing innovative work. This, of course, does not mean that Skive is without challenges when it comes to boosting local employment and economic development opportunities. This study has highlighted potential opportunities to improve actions taken at the local level.

Figure 2.1 OECD Gap Assessment Results for Skive

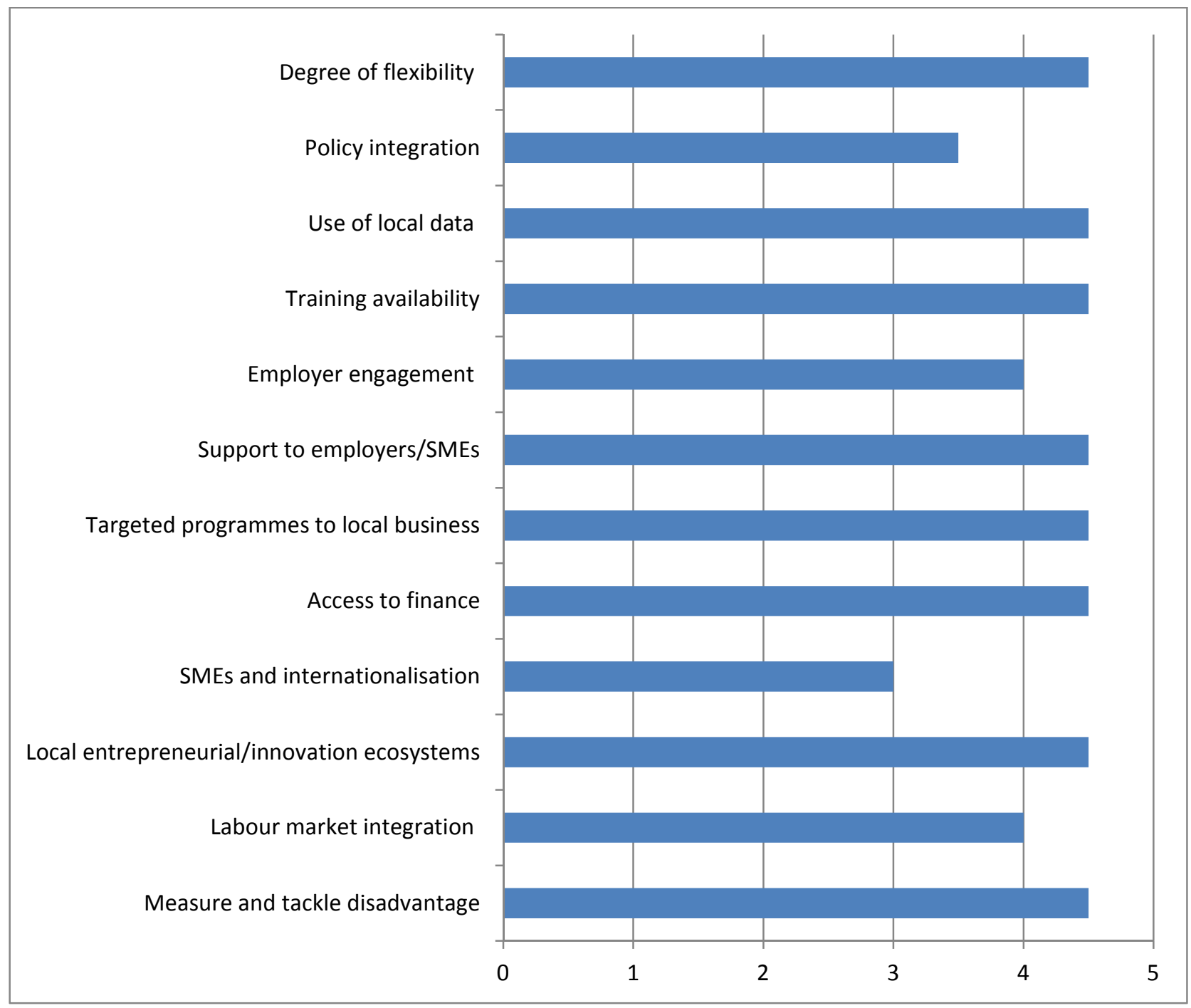




\section{Theme 1: Co-ordination between employment, skills and economic development policies}

Figure 2.2 Assessment results for co-ordination between employment, skills and economic development policies

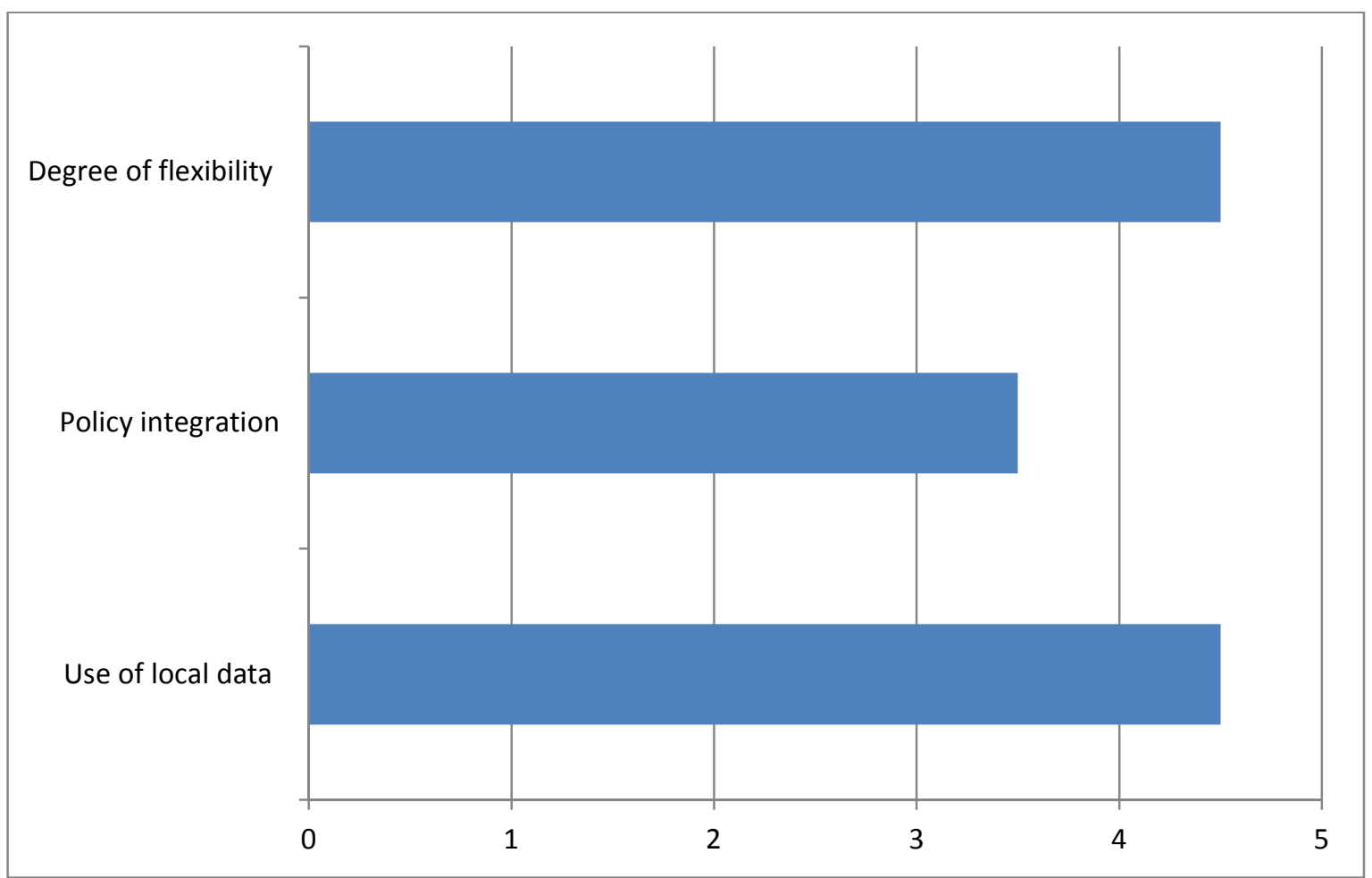

\section{Degree of flexibility in designing and implementing policies and initiatives}

The OECD defines flexibility as 'the possibility to adjust policy at its various design, implementation and delivery stages to make it better adapted to local contexts, actions carried out by other organisations, strategies being pursued, and challenges and opportunities faced' (Giguère and Froy, 2009). Flexibility deals with the latitude that exists in the management of the employment system, rather than the flexibility in the labour market itself. The achievement of local flexibility does not necessarily mean that governments need to politically decentralise (Giguère and Froy, 2009). Governments just need to give sufficient latitude when allocating responsibilities in the fields of designing policies and programmes; managing budgets; setting performance targets; deciding on eligibility; and outsourcing services.

Employment and labour market policy in Denmark is characterised by the so-called "flexicurity" model which enables flexible arrangements for employers to terminate employment arrangements, while at the same time offering relatively high unemployment benefits to those temporarily unemployed.

Employment policies in Denmark are in a period of transition due to the introduction of new reforms. Public employment services (PES) at the local level in Denmark was moved from state authority to the municipal level in 2007. Following this a rather detailed level of control on processes and activities were introduced. In 2015, new reforms are being introduced which place a growing focus on outcomes in relation to sustainable job placements as opposed to compliance with processes and activities. The expectation is that this will enhance the local autonomy once implemented. Previous OECD work noted that it was necessary to reduce unnecessary bureaucracy within the management system so that local job centres have the capacity and time to fully contribute to local employment strategies (Mploy, 2011). 
Danish labour market policy is implemented through a number of programmes which provide strong autonomy at the local level. There are a number of specific training programmes directed at specific target group which are designed at the national level (e.g. scerligt tilrettelagt ungdomuddannelse). At the same time local PES offices are given broad criteria to design local initiatives targeting specific disadvantaged groups, which may require more specific services depending on the local labour market characteristics.

In many instances, the capacity of the local PES office impacts the ability to effectively use the flexibility provided from the national level. In general, Skive demonstrates strong ability at the local level in the implementation of employment programmes. The local PES office in Skive is managed through the municipality and programmes are thus well coordinated with other policies and programmes. One example is the "Straksuddannelse" (immediate education) programme which helps unemployed youth to go back in education in order to qualify for unemployment benefits. Through close cooperation with the local educational institutions, the local PES was able to offer open courses with short notice.

A previous OECD study noted that the complexity of the management system places great demands on political and administrative managers, which can make it difficult for local politicians and administrative management to identify and clarify the local strategic latitude to make a difference (Mploy, 2011). When looking at accountability and performance management of the PES, this is primarily done through reporting from the municipality. An employment plan, which takes into consideration targets set at the national and regional level (Beskceftigelsesplan), is prepared annually. Overall results and outcomes can be monitored through different sources. A particularly good example is a database implemented by the Danish Agency on Labour Market and Recruitment (e.g. www.jobindsats.dk). This platform monitors national, regional and local targets and presents timely information on PES offices performance in terms of programme delivery and funding as well as employment benefit recipients' characteristics.

Thanks to this platform, local offices are able to compare themselves with other offices in the same regions or in a similar labour market and to assess their performance over time. The delivery of local employment services in relation to active measures, including training and education, is decided locally and there is widespread autonomy. A number of different providers can deliver services and the choice is generally made on the basis of the immediate needs. Typical service providers could be local educational institutions providing training courses, or private providers specialising in services for specific target groups (e.g. unemployed with higher education).

\section{Degree of integration between employment, skills and economic development}

In Skive there is general coordination between the different policy areas; however the majority of coordination occurs through informal communication and networks. There appears to be a "culture of cooperation", where local stakeholders have a shared understanding and vision and a genuine wish to cooperate as well as to create growth and economic development in Skive.

This informal nature of the local networks could be challenged for example when key people within government organisations assume other positions (e.g. take another job) and leave the network. During the OECD workshop, this type of fragility was acknowledged among participants. At the same time, the current state of informal collaboration allows a quick response to local labour market challenges and doesn't seem to preclude policy integration. 


\section{Box 2.1 BIG BLUE SKIVE 2040}

On the occasion of its $25^{\text {th }}$ anniversary, Skive received a donation from the local fund Spar Vest Fonden. The donation included a development strategy for the city of Skive elaborated by the Danish architects BIG (Bjarke Ingels Group) called Big Blue 2040.

The purpose of the strategy is to help Skive become more attractive for new people and workers by developing the city centre with new apartment blocks, office buildings and leisure activities that build upon and connect with the unique selling points of Skive: the locals, water, food and energy.

In particular, there is a very strong focus on strengthening the attractiveness of the waterfront in the bay area (Skive Fjord) as well as the creek that runs through Skive (Karup $\AA$ ). In the coming period the master plan will be discussed and will represent the basis for further initiatives.

Source: http://www.skive.dk/kommune-politik/politikker-kort-og-planer/planer/big-blue-skive-2040/ (in Danish)

While Big Blue 2040 articulates a forward looking vision of economic development in Skive, overall, there is no formal strategy or vision which integrates employment, skills, and economic development policies. Each policy area has its own programmes and initiatives and while there is some information sharing, the extent of joined-up work is ad-hoc; therefore there is an opportunity to improve policy coordination and integration in Skive.

Previous OECD research noted that municipalities are well placed to play a significant role in combining an approach which meets both individual and community needs (Mploy, 2011). They have the potential to work across policy silos and take broad community issues into account when planning employment policies and programmes.

\section{Degree of utilisation of local data in evidence-based policy making}

Danish labour market policy has focused increasingly on implementing 'what works' in terms of improving employment outcomes for job seekers, through an evidence-based approach. This thinking has fed into the development of minimum standards in the service to job seekers, and into rewarding municipalities for taking forward actions for which there is evidence of good outcomes. Denmark is not alone in moving towards an evidence-based approach for labour market policy, but the availability of longitudinal data on the outcomes of investment in training and education on job seekers would seem to make this approach particularly valuable.

Overall, data availability and analysis appear to be quite robust in Denmark. Data is generally available both at the national and local levels, enabling stakeholders in Skive to analyse and evaluate the impact of their actions. As previously mentioned there is a national database called jobindsats.dk providing access to a range of performance indicators and benchmarks at the national and local level. Another very clear example of the strong use of evidence based policy making is the yearly employment plan for the local PES (Beskaftigelsesplan), which defines clear targets and monitors the effects of the programmes and initiatives every year. ${ }^{3}$ It is thus the general impression that data is leveraged to support strategies, decision making and evaluations.

\footnotetext{
${ }^{3}$ http://www.skive.dk/borger/arbejde-ledighed-og-pension/beskaeftigelsesplan-og-resultatrevision/ (Access to all employment plans from 2010-2015 - in Danish.)
} 
The OECD has noted that the role of the National Labour Market Authority and the employment regions is essential in sharing good practice and research findings, and ensuring that the sum of local actions allows Denmark to meet national employment policy objectives (Mploy, 2011).

\section{Theme 2: Creating productive economies}

Figure 2.3 Assessment results for creating productive economies

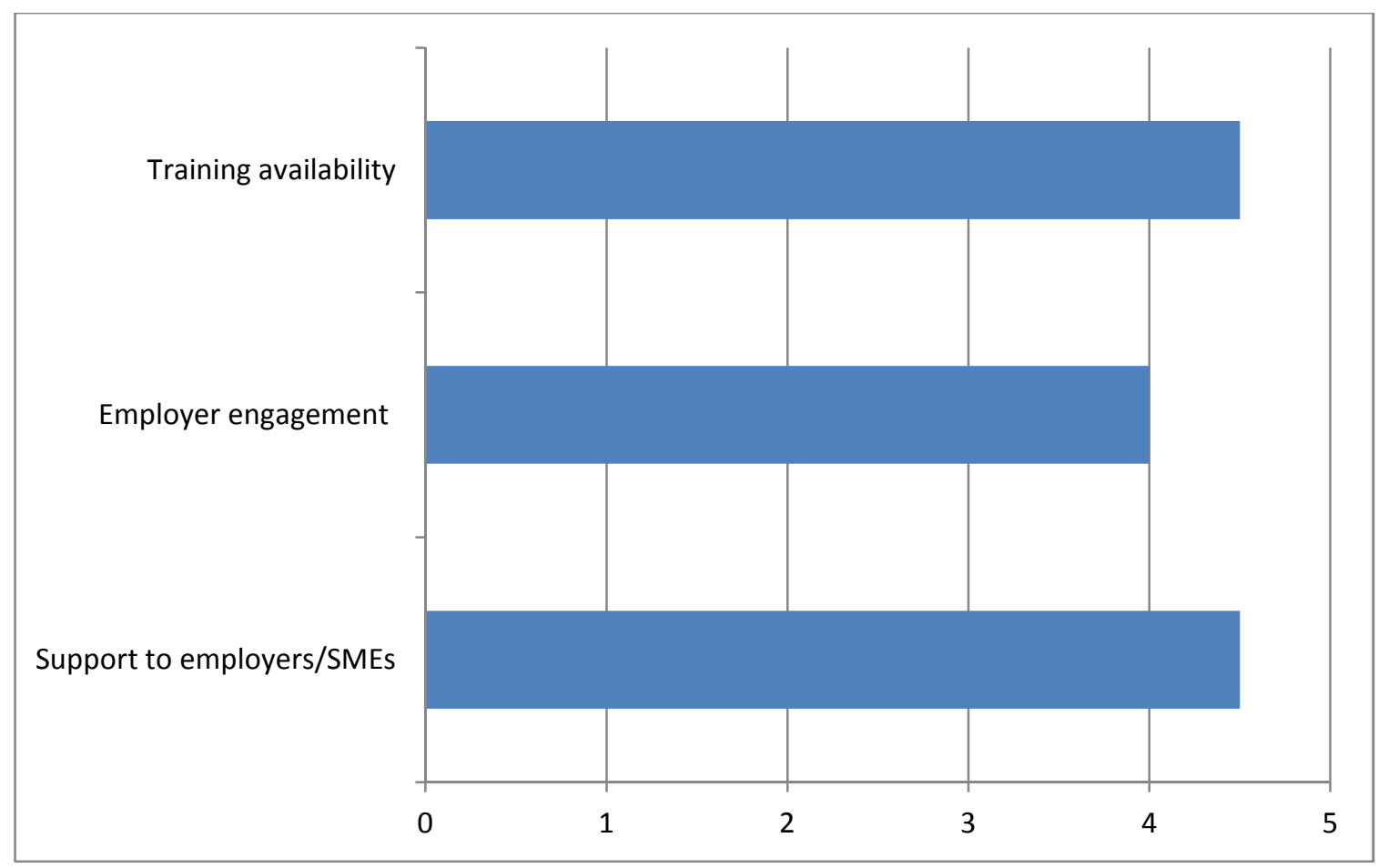

Extent to which training is available in a broad range of sectors, flexible and accommodating the needs of workers and unemployed individuals

In Denmark, postsecondary VET assumes two main forms: academy profession programmes and professional bachelor programmes (Field et al, 2012). Training towards blue collar workers is typically offered through public and/or not for profit enterprises, whereas white collar workers usually receive training from private enterprises. In most cases, training is free of charge for participants and is funded through regular state programmes, the local PES or the employers (especially white collar). The training system is generally responsive to employer need. The OECD's recent Economic Survey of Denmark notes that VET, in which about $20 \%$ of students enrol, suffers from high drop-out rates, especially among students with an immigrant background, leaving some with poor skills (OECD, 2014).

There are a number of educational institutions offering training in Skive, including Skive Technical Institute offering vocational training and upper secondary education (HTX), Dania Academy of Higher Education offering short higher educational programmes, and VIA University College offering higher education. The offer of courses provided locally is comprehensive and this contributes to enhance the supply of skills. There is growing specialisation among training suppliers which means some training courses can only be attended in a few geographical locations in Denmark. As an example, Skive Technical Institute provides training to about $90 \%$ of all Toolmakers in Denmark and thus holds a strong specialisation in this particular area. 


\section{Box 2.2 Training courses at Skive Technical Institute}

Skive Technical Institute offers a wide range of courses, ranging from professional and technical courses to courses in soft skills courses, human resources and management of new challenges. They are also specialised in the areas of leadership, communication and co-operation, LEAN, work environment and job satisfaction. In order to complete the training, a training period in a company is also required.

Thanks to the close co-operation with the companies, the courses are continuously restructured and updated in order to provide them with the knowledge and tools they actually need (AMU-kurser).

Skive Technical Institute has many years of experience in offering professional advice both to the private and public sectors. In addition, Skive Technical Institute provides the largest share of training in the wood industry sector in Denmark.

Source: Available at https://www.masterpiece.dk/UploadetFiles/11741/36/SkiveTechnicallnstitue.pdf

\section{Degree of employer engagement in orienting skills development to demand and extent to which training meets business needs}

It is essential to ensure the correct match between the demand for training and the supply offered to employees and jobseekers. This match between supply and demand is eased through involvement and engagement of the employers. Previous studies (Field et al, 2012; CEDEFOP, 2011) have highlighted the level and quality of employer engagement in Denmark as high when compared to other European countries. Tripartite co-operation between trade unions, employers' organisations and the State is a key characteristic feature of the Danish labour market model (Hendeliowitz, 2008).

In Skive the demand for training is managed mainly through local dialogue with employers. Several different actors approach local companies. Educational institutions approach the companies directly, and the VEU Centres canvass local companies to supply specific training programmes. Training can be customised for the specific companies and also within different sectors (e.g. the manufacturing industry, retail, transport and services). Senior level executives in the municipality have regular meetings with local employers and the local business development centre also canvasses both local SMEs and larger enterprises. Dialogue with employers and SMEs seems quite widespread in the municipality.

\section{Box 2.3 Working with employers on training}

Skive Technical Institute identified a training need in the field of control systems for CNC (computerized numerical control) machines and developed a strategic partnership with Siemens in this field. Thanks to this partnership, Skive Technical Institute has been accredited Siemens training partner and companies in the whole country are referred to it for training. Skive Technical Institute on their part ensures that their teachers are up to date through a requirement to attend training at least once a year at Siemens.

Furthermore, there are a number of programmes designed at the national level, where employers are also involved. Another channel where demand for training is discussed is the Local Employment Council (Det lokale beskceftigelsesrad)) which is a forum of unions, employers' organisations and the local PES. Due to the recent reforms, the local council was dissolved and now there is only a committee at the regional level. During the interviews conducted for this study, it was revealed that the local representatives in Skive have decided to continue with the local forum to ensure that dialogue is open at the local level. 
Overall the impression is that the training and courses offered are in line with the demand from local enterprises. There are examples of local enterprises reporting needs for specialised training, for example training in e-business within the information technology sector, but these are relatively few instances.

\section{Degree of support to employers/SMEs in maximising skills utilisation, improving work organisation, human resource management, workforce planning and skills development}

Job creation can be supported in SMEs by improving skills utilisation, development and human resource management approaches. In Skive, there are several actors supporting local employers and SMEs in this area. First of all the local business development centre provides "first line" support. If a need for more specialises training arises, strategies and programmes which target SMEs are available at the regional level (Voeksthuset). Usually the local business development centre is in contact with local SMEs as they engage in more specialised projects. The role of the local business development centre has become a key account manager on behalf of the overall business development efforts both locally and regionally. The typical project focus is on leadership and management, strategy, and internationalisation.

Another dimension of business development is attracting talent and developing skills. This could be done by attracting students or new graduates to local employers/SMEs. There are no overall formal institutions connecting students to employers/SMEs in Skive, but there is a successful local initiative called Careers in Skive (KIS-Huset). Through this initiative, students who decide to take up a project in a local company in Skive are also offered accommodation fully financed by local employers. The idea is to make it easy and attractive to come to Skive.

\section{Box 2.4 Careers in Skive}

Local companies in Skive identified a challenge related to attracting a workforce with relevant competencies. As a consequence they have established KIS-Huset (The Career in Skive House). The idea is to offer affordable housing to short term interns and/or new graduates in their first job. The hope is that by offering local housing the newcomers will permanently settle in Skive instead of commuting. The house has been financed through the local employers and offer 13 apartments.

Source: Available at http://issuu.com/kulturskive/docs/a4 info kis-huset en lowres 


\section{Theme 3: Supporting entrepreneurship and economic development}

Figure 2.4 Assessment results for supporting entrepreneurship and economic development

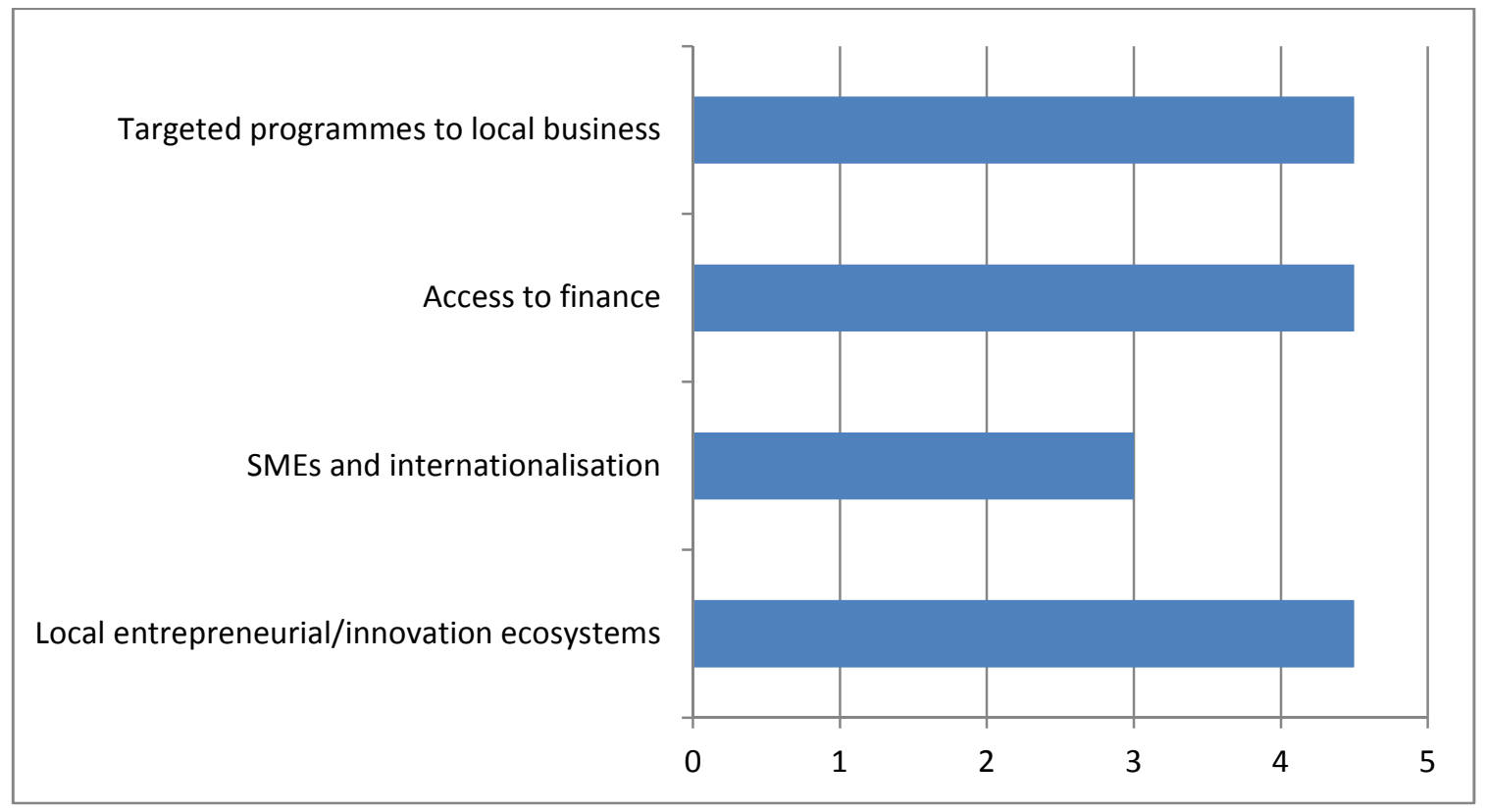

Extent to which programmes and services are adapted to local business demographics and profiles, addressing SME needs

SMEs account for $99.4 \%$ of all enterprise in Denmark (OECD, 2015). It is important that the programmes and initiatives at the local level are adapted to the structural needs of the economy. In Skive policy making is generally based on a comprehensive analysis thanks to the strong availability of data. Furthermore, there is a tool developed for performance management at the national level particularly for the employment area. This guides policymaking at the national, regional and local level.

As a result of the data driven policymaking some of the areas of particular focus that have been identified are sustainability, green economy and sectors that are vulnerable to technological changes. This is also mirrored in local programmes and initiatives especially within the "green economy" and sustainability (e.g. the range of projects under the initiative www.energibyenskive.dk).

\section{Box 2.5 Energibyen Skive}

In recent years, Skive municipality has increased its efforts to become even more energy efficient and optimize energy saving measures and has set the standards for climate and energy strategies across the country. Skive municipality will continue, to involve the citizens and organisations in order to create an even more independent and sustainable society, which will benefit everyone living and working in Skive.

As a result of these efforts, Skive was appointed as one of Denmark's first 'Energiby' in October 2008. Skive's Climate and Energy Strategy 2029 defines the goals and frameworks for how Skive municipality -to become CO2-neutral. Within a few years, the first power-to-gas test facility in Europe is scheduled to open north of the city of Skive. Green Lab Skive is development project between Skive Municipalitiy, universities and a range of public and private organisations from Denmark as well as from abroad. 


\section{Degree of access to finance by SMEs}

Overall SMEs can get access to funding in Denmark when they are able to present a viable and trustworthy business plan. SME access to finance is managed by Vaekstfonden (The Danish Growth Fund), a government investment fund created in 1992 (OECD, 2015). Vaekstfonden offers guarantees and loans to established SMEs and entrepreneurs, invests equity in young companies with growth potential and has a fund focusing on both venture and the SME segment (OECD, 2015).

The OECD's SME Scoreboard notes that financial institutions lending to SMEs, approximated by loans which amount to less than EUR 1 million, declined by around 30\% between 2007 and 2009 and recovered afterwards. There was a large increase of 23\% of new SME loans in 2013 and marked the first year where new SME loans surpassed the pre-crisis level of 2007 (OECD, 2015).

However, venture capital for new growing firms is less so than in some other Nordic countries and it declined by $60 \%$ between 2007 and 2012 due to the crisis (OECD, 2014). The OECD recent Economic Survey of Denmark notes that Denmark has a balanced mix of R\&D tax incentives for firms and direct government support to business R\&D (OECD, 2014).

There are a number of initiatives both nationally and locally aimed at providing funding to SMEs. At the national level it is worth mentioning Veekstfonden which provides capital to companies across Denmark. In Skive there is an initiative called Business Innovation Denmark which includes cooperation among local investors to provide capital.

\section{Box 2.6 Business Innovation Denmark}

In 2007 the loudspeaker manufacturing company JAMO, one of the largest companies in Europe, closed the production in Glyngøre in the municipality of Skive. This left a challenge for business development locally. In order to promote local economic development, 14 local shareholders together with a local fund (Spar Vest Fonden) established Business Innovation Denmark as a local centre for entrepreneurship also providing seed capital. This initiative is financed by the private sector.

\section{Extent to which SMEs are helped to benefit from internationalisation opportunities}

In a small open economy as Denmark, it is important to be able to leverage the potential of internationalising businesses. In Skive the local business development centre provides advice on internationalisation opportunities. They can furthermore involve the regional level if they experience that their own competencies are insufficient. Until now, there have not been efforts where larger local companies support SMEs in their internationalisation.

\section{Degree of development of local entrepreneurial/innovation ecosystems and extent of knowledge-sharing}

Skive has a relatively high level of self-employment in comparison to the regional and national level ( $8.3 \%$ in Skive versus $7.1 \%$ in Denmark). In Skive, entrepreneurship is supported through the local business development centre, where courses are offered to all entrepreneurs. The efforts to promote and support entrepreneurship locally are also supported through a number of initiatives available at the 
national level (e.g. Entrepreneurial Pilot ${ }^{4}$ and Go Grow ${ }^{5}$ ). These programmes can provide knowledge and training as well as funding to entrepreneurs.

In the formal education system, the integration of entrepreneurship in the traditional coursework varies significantly across institutions. In Skive, there is a local initiative called "Next Step" focusing on youth entrepreneurship, which is a cross sectoral cooperation between several education institutions and the local business development centre. One of their activities is to organise an entrepreneurship day.

\section{Theme 4: Ensure growth is inclusive}

Figure 2.5 Assessment results for ensuring growth is inclusive

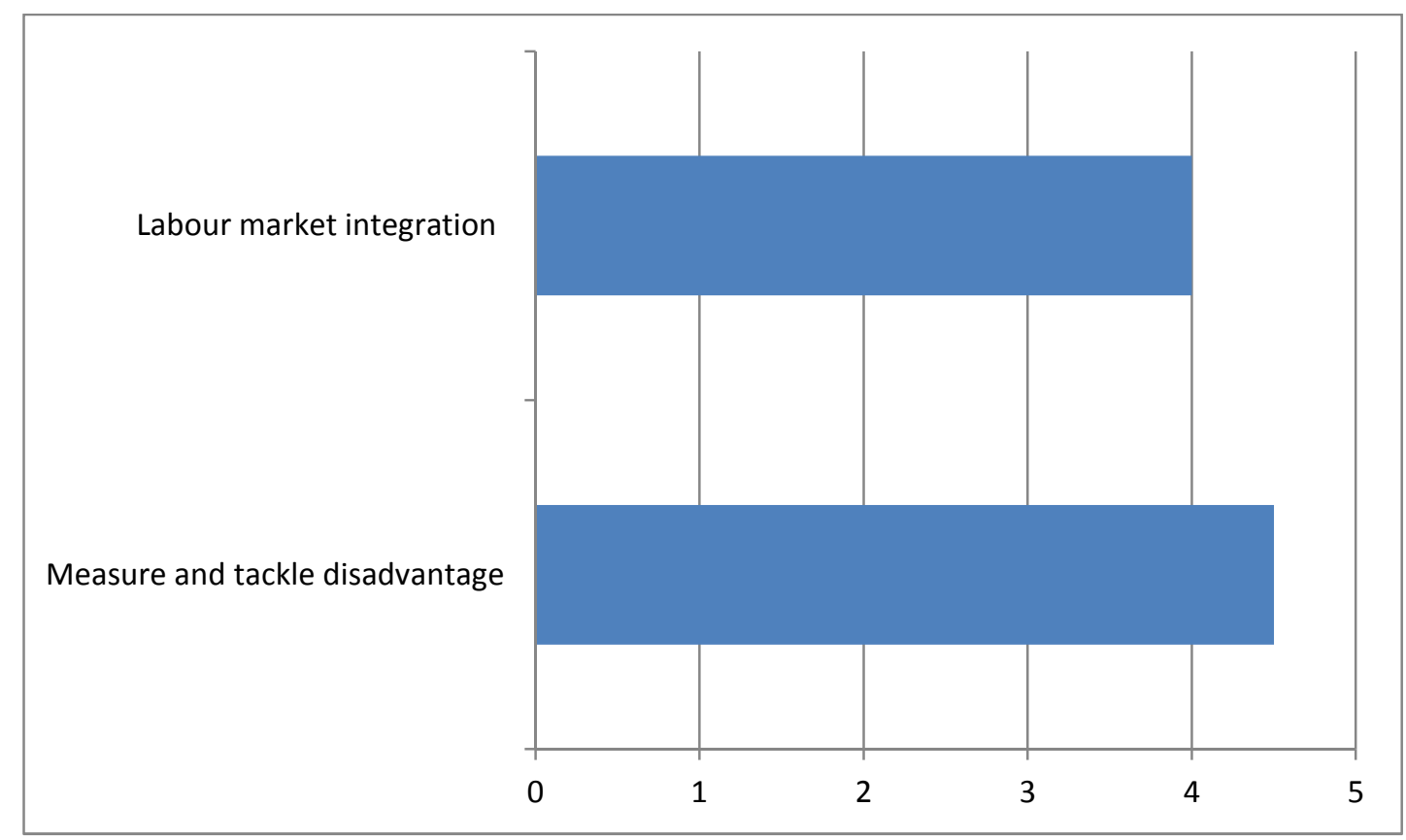

Extent to which effective policies are in place to support the labour market integration of disadvantaged groups and degree of flexibility in adapting programmes to different target groups

Thanks to the low unemployment rate, policies and programmes in Skive have a strong focus on vulnerable groups and policymakers have shown flexibility to adapt the initiatives to their specific needs. However challenges still exist in reaching some disadvantaged people that have issues like housing or sickness in addition to challenges related to employment and education. A successful example is a local programme targeting young people affected by the Aspergers Syndrome. After taking part in this initiative, $80 \%$ of the participants were either in permanent jobs or in ordinary education.

Skive is experiencing positive net migration and this requires initiatives targeted at newcomers. In order to ease immigrants labour market integration, there is a skills evaluation system (realkompetencevurdering) that assesses to which extent their skills can be converted and if they need additional training. For specialised and certified professions there are additional measures to evaluate skills levels.

\footnotetext{
${ }^{4}$ http://innovationsfonden.dk/en/investment/entrepreneurial-pilot

${ }^{5}$ http://go-grow.dk/
} 
Another area is to avoid informal employment and/or help people out of informal and illegal employment. Locally there are regular inspections by local and state authorities, for example tax audits, social services and working environment authority that usually reveal irregularities. Furthermore, the different public authorities can cooperate on audits and have possibilities to sanction companies. Another source is also the local unions who monitor firms showing suspicious employment conditions.

Extent to which there are evidence-based tools used to measure disadvantage on the labour market and support multi-stakeholder approaches to tackling disadvantage

Skive has been at the forefront of developing initiatives targeted at disadvantaged groups. Locally there has been a successful initiative targeting youth by offering them immediate education the day after they have applied for unemployment benefits (straksuddannelse). This initiative targets all unemployed youth under 30 years and the education offered is tailor-made so that the scope is in line with the capabilities of the individual. This initiative has been quite successful and is being adopted in other municipalities.

Another successful initiative at the municipal level is addressed to the long-term unemployed. The initiative ensures that there is a special advisor appointed to the individuals once they reach 78 weeks of unemployment and thus approach the limit of receiving benefits. This is also an instrument which spans multiple stakeholders. 


\section{Section 3}

TOWARDS AN ACTION PLAN FOR SKIVE: RECOMMENDATIONS AND BEST PRACTICES

Stimulating job creation at the local level requires integrated actions across employment, training, and economic development portfolios. This requires flexible policy management frameworks, information, and integrated partnerships which leverage the efforts of local stakeholders. This section outlines the key recommendations emerging from the review of local policies in Skive. 


\section{Co-ordination between employment, skills and economic development policies}

\section{Recommendation: Strengthen local policy cooperation and coordination by fostering partnerships, which can effectively design and implement employment and skills strategies}

Overall there is a relatively high degree of flexibility in designing and implementing policies to strengthen job creation at the local level in Denmark. As a result, local employment offices in Skive has the ability to adjustment programmes and policies to local labour market conditions as well as to individual groups who may require more specialised and customised supports and interventions. In Skive, policies are well integrated with the business development and employment sectors, but to a lesser extent with the education sector. This is area that could be strengthened and further developed.

Partnerships represent a key governance tool to better connect the supply and demand of skills to ensure greater economic growth and productivity. Employment services need to collaborate locally with skills and economic development actors. In Skive, there is room for the employment services and area partnerships to strengthen horizontal collaboration, and to identify the effectiveness of activation and training programmes. A lack of policy coherence between these policy areas can create unintended consequences, which lead to sub-optimal interventions for individuals who require more intensive services, which include both income support and employment services.

\section{Box 3.1 How to build successful partnerships?}

A locally-based partnership is usually designed to bring together all relevant actors within a region to address a specific issue within a community and/or improve its overall economic well-being. However, bringing together all relevant actors is not an easy task as this implies having around one table not only different government institutions (usually of different levels), but also social partners, employers, NGOs, training institutions, and representatives of civil society. Whatever the reason to set up a partnership, there are certain factors to bear in mind:

- Organisational structure: To be efficient, a partnership should have recognisable and autonomous structure to help establish its identity. The structure should have stability and permanence as well as flexibility, and it is helpful if there is a certain independence from political influence. It is also important to review lines of communication to ensure that all partners are kept informed and involved. Equity should be a guiding principle in building a partnership, as should (for many partnerships) a "bottom-up" structure. Sufficient human and financial resources are also needed.

- $\quad$ Preparation: Preparatory work is crucial for developing a steady and effective partnership. Careful research into the context in which the partnership will be operating must be part of this phase. The strengths and weaknesses of the area should be assessed and effective measures designed. One of the most important aspects of this phase is to identify the right partners and establish clear roles for each.

- Work plan: Partnerships need to develop a long-term strategy if they are to work effectively and have a lasting effect. For area based partnerships, this strategy should include a vision for the region, focusing on the outcome to be achieved, an action plan identifying shorter-term priorities, and a co-ordinated working programme including activities and measures that will contribute to the achievement of long-term outcomes. The work programme should indicate the interests and targets of all partners and include activities and measures that will contribute to the improvement of the territory.

- Implementation: In this phase partners are in regular contact to co-ordinate implementation, to extend and supplement the working programme with new measures, and in some cases to test new approaches. Public relations activities should inform the wider public of the targets, activities and measures of the partnership.

- Monitoring: To assess a partnership's achievements, determine improvements to be made and adapt further planning, a comprehensive monitoring system should be used. A partnership should be evaluated 
periodically and publish reports to demonstrate the added value of its work.

Source: OECD (2014), Job Creation and Local Economic Development, OECD Publishing. DOI: $\underline{10.1787 / 9789264215009-e n}$

Policies are developed through strong informal collaboration with no articulated common vision for the region and community. While this can be viewed as a strength, it is necessary to examine the potential trade-offs between informal and formal collaboration. The possibility of formalising local collaboration in Skive could contribute to the development of strategic objectives for the region and related actions and priorities. It would also mitigate the potential risks involved when a key individual leaves an organisation where there may be strong collaboration.

It is recommended that Skive establish a local board and/or committee which would be tasked with the development of a job creation and skills strategy for the community. This strategy should seek to articulate short, medium and long-term priorities for the region as well as potential policies and programmes, which would need to be future developed to support the identified priorities. The implementation of this strategy should involve key stakeholders from the employment, education and economic development areas as well as employers. It would build on the Big Blue Skive 2040 Strategy by formalising governance arrangements across the various policy portfolios through the establishment of a committee and/or board.

\section{Box 3.2 Establishing a formal partnership to adjust to structural changes - example from Sweden}

The closing down of the Ericsson plant for fibre optics in Hudiksvall was one in a series of unfortunate events in a county which was hit by several closings and restructurings. It was obvious from the start that the loss of 318 jobs would have a significant impact on this small town. In response, the local government of Hudiksvall organised a regional partnership known as the group for strategic co-ordination to deliver a package of futurerelated actions("strategisk samordningsgrupp för Framtidspaket Hudiksvall").

This group illustrates the commitment by a large number of organisations to help in various ways. Furthermore, the readiness to form the group shows the level of collaboration in this region. Some of the members are leading politicians, in Hudiksvall (including the mayor), and the elected chairman of Region Gävleborg. One is the county prefect (landshövdingen), appointed by the government. The head of the local office of Arbetsförmedlingen (Swedish Public Employment Service) is in the group, as well as the vice-chancellors of two universities and the head of the research corporation for what is known as the Fiber Optic Valley. The group also includes the head of business promotion in Hudiksvall, representatives of two unions and the national human resource director at Ericsson.

The partnership worked with three ambitions. One was to take action within employment policy, to find new jobs. Another was to work with business development and innovation, to commercialise ideas developed by the staff of Ericsson. The third was to work with other companies which showed an interest in hiring the staff who risked being unemployed. There are specialized groups working with the first two tasks, as well as a group for the day to day co-ordination of actions across organisational boundaries.

Source: OECD (2015), Employment and Skills Strategies in Sweden, OECD Reviews on Local Job Creation, OECD Publishing, Paris. DOI: http://dx.doi.org/10.1787/9789264228641-en 
Recommendation: Promote and sharing information and data across public sector organisations and coordinate efforts in reaching out to employers to deliver government services in an efficient manner

Skive should consider how best to share information and data across public sector organisations in reaching out to employers to deliver government services in a more coordinated manner. In Skive, there are a number of stakeholders who work with employers to examine their labour, skills, and business development needs. A key policy issue is how to get companies to participate in government services. A more coordinated response could be more efficient in approaching local employers and involving them in efforts to promote economic development opportunities in the community. Data and information can also be the "glue" which stimulates partnership working and enables various stakeholders to come up with a common vision and objectives for the region based on a shared understanding of the key labour market and economic challenges.

\section{Box 3.2 Workforce Intelligence Network - Michigan, United States}

The Workforce Intelligence Network (WIN) is a collaborative effort between seven local workforce boards, nine community colleges, and economic development partners to build and share labour market intelligence and help consortium members, particularly community colleges, make better "real time" decisions regarding skill gaps. One of the tools used by WIN is a methodology to search the internet for job openings and resumes. This information, combined with data from the state's labor market information and special surveys, are incorporated in strategic plans and operational decisions.

For example, one local workforce board, SEMCA has used information on emerging industry needs to create a local talent pool for "computerised numerical control and welding". Each year it also completes a "Region Top Jobs" report, which includes the availability of current and projected opportunities by occupation, with the number of openings, and the rates of pay.

In the area of information technology, which are some of the fastest growing in the region, WIN's cluster strategy includes the convening of an employer-led, multi-industry council, which has come to be known as the Tech Council of Southeast Michigan. The Council is convened to raise awareness of and shape community responses to regional talent needs. This group meets routinely and has two primary focuses:

- Talent attraction and development.

- Marketing and branding Southeast Michigan as a technology hub.

The Council is comprised of more than 30 employers who have a significant need for information technology talent and is open to any additional company who may be interested in participating. WIN is directly involved with company-led training initiatives like "IT in the D" and serves as a communication conduit for the region's various talent partners.WIN is also working closely with the Michigan Economic Development Corporation, the state of Michigan, business accelerators, and many others to collaborate and help drive their efforts and programs aimed at closing the IT talent gap in Southeast Michigan.

Source: OECD (2014), Employment and Skills Strategies in the United States, OECD Reviews on Local Job Creation, OECD Publishing. DOI: 10.1787/9789264209398-en

Recommendations: Expand capacity building and peer learning activities through partnerships with neighbouring localities in Denmark and internationally

Skive should continue to look for opportunities to learn about what works in the areas of employment and economic development. This would involve the organisation of capacity building events and seminars, which would bring together other Danish regions, as well as international experts to share learning and 
experiences about successful local employment and economic development strategies. Skive could benefit from working together on joint development projects with other municipalities in different priority areas to attain broader cooperation with employers over a larger geographical area

There is also a clear opportunity to continue engagement with the OECD through its network of local practitioners involved in local employment and economic development. Each year, an annual networking event is organised to bring together international representatives to discuss the latest policy innovations and employment challenges. Skive should continue to be an active member of this network, which can provide learning opportunities as well as key government contacts in other countries for mutual learning.

\section{Creating productive economies}

Recommendations: Expand collaboration between universities, educational institutions, and employers to stimulate innovation and productivity

The gap assessment reveals that Skive performs relatively well in this area. Skive is able to offer training demanded locally within the municipality. There is elaborate cooperation between employers/SMEs and the local stakeholders both in relation to the design and the supply of the training courses. Local SMEs are proactively supported in relation to training and business development by the municipality but also regionally for the more specialised topics. In the future, local training institutions in Skive should invest in the provision of more specialised training courses in response to the needs of local employers

In order to stimulate stronger job creation and productivity, local stakeholders in Skive should strengthen and expand collaboration between universities, educational institutions, and employers to intensify research and development as well as innovation opportunities. The collaboration with the universities will also have an impact on connecting students with local enterprises and ensure their stay in the region after the end of the studies. The KIS-Huset project goes in this direction but should be furthered developed and extended to a broader audience.

Recommendations: Better aligning the training system with employers by strengthening the skills and competences of VET personnel

To boost productivity and innovation, it is important that training opportunities provided by the vocational education and training system are well aligned to the needs to local employers. Better aligning the employment and training system with employer demand will help to reduce potential skills mismatches and make more efficient of the use skills being produced by the education system. This means that the skills developed should correspond to the requirements of the jobs that are available in Skive. To ensure that supply is adequately meeting demand, local VET institutions need to adapt the mix of provision and curricula to local needs.

Often, there can be a credibility gap between the knowledge being gained within the VET system and the real world skills required to perform a job within local sectors of importance. For Skive, it is important to continue improving cooperation and partnerships between local employers and the training sector. On the employer side, it is important that efforts are being made to coordinate the skills needs of industry and that this process is well articulated. On the supply side, it is important to ensure that training curricula reflects the demand of industry.

In other OECD countries, often, industry representatives are used as trainers working with the VET institution. This helps to build credibility of a VET institution and ensure that the equipment and training materials being used in the classroom reflect real world experiences. Going forward, Skive should seek to 
strengthen the capacity and skills of VET personnel to ensure that they are have adequate capacities and skills.

\section{Supporting entrepreneurship and economic development}

Recommendation: Stimulate quality employment through policies which promote the better utilisation of skills in the workplace

One of the significant labour market challenges facing Skive is how to raise the productive capacity of existing firms. This area of policy is important for Skive and the community seeks to raise the overall quality of jobs on offer. There is an opportunity for public actors to take a stronger role in working with employers to raise awareness about the importance of better utilising skills. Incentives could be offered to employers to undertake initiatives, which look at current organisational and human resources management practices.

OECD research shows that for local areas that are stuck in low skills equilibrium, technical assistance, management training, and embedding skills policies in broader mechanisms for business support can encourage demand for higher levels of skills (OECD, 2014). In low-skills equilibrium regions, local employers offer low-skilled jobs and operate in low-cost markets, so there are few high quality jobs available.

Knowledge-sharing networks can play an important role in promoting such non-technological innovation, both within sectors and across sectors. While some knowledge sharing networks may be purely private sector, universities and vocational training schools can also help inject new ideas and new technologies into such networks, particularly when they carry out relevant applied research.

\section{Box 3.3 Practice Labs in Flanders, Belgium}

In Limburg in Flanders, practice labs for innovative work organisation have been set up to work with businesses on work organisation issues. The ACV union has played a key role in establishing and implementing the initiative. The practice labs have been set up in the construction, logistics, healthcare, social economy, social service/care sector and agricultural sectors. Separate labs were established for each sector but in fact, labs can work with mixed groups, and can support both large and small firms.

Eight workshops have taken place in 2013/14, each involving 6-8 companies. A consultant was hired to work on the workshops. They function as a learning network where companies share experience. Managers are encouraged to consider where they can effect change to make sure that workers have more involvement in the way that the firm operates.

Each lab covers seven themes, each of which is a different area where the manager can have an influence. This includes exploring new ways that firms can expand their market base to improve the quality of their organisation (in terms of efficiency, flexibility, quality, innovation, sustainability) while also improving job quality. Supervisors play the role of coach and act as a sounding board for participants who have questions, both within and outside of the lab sessions. Participants receive assignments to translate theory into practice when they return to the workplace. Unions report that the workshops have improved their relationships with local employers.

Source: OECD (2015), Employment and Skills Strategies in Flanders, Belgium, OECD Reviews on Local Job Creation, OECD Publishing, Paris. DOI: http://dx.doi.org/10.1787/9789264228740-en 
Entrepreneurship has a crucial role to play in modern societies due to its contribution to the generation of new ideas, innovation, job creation and economic growth. It has potential for creating jobs and reducing unemployment, not just in the population in general, but also among people who are vulnerable to social exclusion (OECD, 2014).

To successfully start up and operate a business, entrepreneurs need to use a wide range of skills. This skill-set includes skills that are required from employees in any workplace, but also those skills needed to respond to the additional demands of running a business (OECD/European Commission, 2013). While some of these skills may not be absolutely necessary for successfully operating a business, possessing them is likely to increase the quality of an entrepreneur's business and the chances that it will be sustainable and grow. It is therefore important to identify the skills needed by entrepreneurs and consider how they may be acquired and strengthened, and how this can be supported by public policy.

The comparative analysis in the gap assessment reveals that Skive performs well. Overall, SMEs are supported in relation to business development and work organisation and the efforts are adapted to the local structures. There are several initiatives both nationally and locally to support entrepreneurship. It is recommended to investigate the possibilities to strengthen the support towards internationalisation further. Local stakeholders can also contribute in connecting some of the larger enterprises with the SMEs. It is recommended to continue with the "Next Step" project and to investigate further the potential to lift the general focus on entrepreneurship.

\section{Box 3.4 Supporting Entrepreneurship in Shawinigan, Canada}

Entrepreneurial activity is seen as one of the keys to diversifying the local economy of Shawinigan. For many years, Shawinigan was an industrial town built around its large electric power facility and heavy industry. Industrialisation brought steady well-paying work in forestry, aluminium production and textiles. The city became a victim of structural changes in the global economy with many employers shutting down their operations. With the impending closure of another enterprise in 2009 , prominent people in the community were brought together to look at the future of the city considering its strengths and weaknesses.

Based on this collaboration, the city is pursuing an approach that looks to develop a community of entrepreneurs and small business operations as a sustainable economic base. What is of particular interest about this approach is the partnership of a number of different actors each guided by a different policy focus (e.g. economic development, education or employment) to implement a local horizontal approach.

The mechanism for this integration was a small amount of funding directed to the municipality by a departing employer. A Diversification Committee was established composed of key funding and government agencies. The committee realised that in order to be effective, they would have to create a common local plan that would inform their vertical accountabilities.

Shawinigan opened the entrepreneurship centre in 2013. It represents a unique project in the province of Québec positioned as a tangible action brought about by the entrepreneurial forum with the collaboration of the Diversification Committee. The entrepreneurship centre is located in an old textile factory which has been completely renovated. The city of Shawinigan advanced CAD 3 million for the project with approximately CAD 2 million coming from other sources. The entrepreneurship centre offers skills development programmes along with other supports that will allow the growth of a critical mass of entrepreneurs. Future entrepreneurs will be supported over a 5 year period:

- The first 18 months focused on training and start-up.

- The second 18 months will be dedicated to management and operations within space provided in the 


Centre.
The final two years will be given to consolidating the operations of the new enterprise and its relocation
into the community.
The textile factory will rent commercial and office space at market rates to established businesses as a way
of generating revenue for the centre.
Source: OECD (2014b), Employment and Skills Strategies in Canada, OECD Reviews on Local Job
Creation, OECD Publishing. DOI: $10.1787 / 9789264209374-e n ;$

\section{Ensure growth is inclusive}

Recommendation: Improve the labour market integration of migrants in order to reduce skills shortages in local industries

The gap assessment reveals that Skive performs quite well in this area. Unemployment is quite low and those unemployed generally have access to good benefits to help them re-enter the labour market. For the disadvantaged, there are many targeted programs and projects aimed at vulnerable groups. Skive has a challenge in relation to attracting skilled labour to local industries - there is a risk of losing growth opportunities.

Available data shows that immigrants have relatively high education levels and improving their integration in the labour market could contribute to reduce skills shortages. Previous OECD studies have recommended language support for all immigrant students across Denmark and measures to ensure that all students develop the higher level language skills needed to succeed in demanding jobs and education programmes (Field et al, 2012).

In Skive, a quicker system of skills and education recognition as well as more intensive language classes could contribute to better connect them with the labour market. To better connect immigrants to local labour market opportunities, Skive could pilot work-based learning programmes and apprenticeship opportunities. Such an approach would seek to build on the high level of skills that immigrants possess and link them to the more practical training needed to connect them to a job.

\section{References}

CEDEFOP (2011), "Vocational Education and Training at Higher Qualification Levels", Research Paper No 15, Publications Office of the European Union.

Froy, F., S. Giguère and M. Meghnagi (2012), Skills for Competitiveness: A Synthesis Report, OECD Local Economic and Employment Development (LEED) Working Papers, No. 2012/09, OECD Publishing. doi: 10.1787/5k98xwskmvr6-en

Froy, F., S. Giguère and A. Hofer (eds.) (2009), Designing Local Skills Strategies, http://dx.doi.org/10.1787/9789264066649-en

Field, S., et al. (2012), A Skills beyond School Review of Denmark, OECD Reviews of Vocational Education and Training, OECD Publishing, Paris, http://dx.doi.org/10.1787/9789264173668-en. 
Hendeliowitz (2008), Danish Employment Policy National Target Setting, Regional Performance Management and Local Delivery, OECD Local Economic and Employment Development (LEED) Working Papers, OECD Publishing, Paris. Available at http://www.oecd.org/employment/leed/40575308.pdf

Mploy (2011), "Building Flexibility and Accountability Into Local Employment Services: Country Report for Denmark", OECD Local Economic and Employment Development (LEED) Working Papers, No. 2011/12, OECD Publishing, Paris. DOI: http://dx.doi.org/10.1787/5kg3mktsn4tf-en

OECD (2015), Employment and Skills Strategies in Sweden, OECD Reviews on Local Job Creation, OECD Publishing, Paris. DOI: http://dx.doi.org/10.1787/9789264228641-en

OECD (2015), Employment and Skills Strategies in Flanders, Belgium, OECD Reviews on Local Job Creation, OECD Publishing, Paris. DOI: http://dx.doi.org/10.1787/9789264228740-en

OECD (2015), Financing SMEs and Entrepreneurs 2015: An OECD Scoreboard, OECD Publishing, Paris. DOI: http://dx.doi.org/10.1787/fin sme ent-2015-en

OECD (2014a), Education at a glance 2014: Denmark country note, available at http://www.oecd.org/edu/Denmark-EAG2014-Country-Note.pdf

OECD (2014b), OECD Economic Surveys: Denmark 2013, OECD Publishing, Paris. DOI: http://dx.doi.org/10.1787/eco_surveys-dnk-2013-en

OECD (2014c), Job Creation and Local Economic Development, OECD Publishing. DOI: $10.1787 / 9789264215009$-en

OECD (2014d), Employment and Skills Strategies in Canada, OECD Reviews on Local Job Creation, OECD Publishing. DOI: 10.1787/9789264209374-en;

OECD (2014e), Employment and Skills Strategies in the United States, OECD Reviews on Local Job Creation, OECD Publishing. DOI: 10.1787/9789264209398-en

OECD (2013) Policy Brief on Youth Entrepreneurship, OECD Publishing, http://www.oecd.org/cfe/leed/Youth\%20entrepreneurship\%20policy\%20brief\%20EN_FINAL.pdf

OECD (2012), the OECD Skills Strategy: Better Skills, Better Jobs, Better Lives: A Strategic Approach to Skills Policies. OECD Publishing, Paris, doi: http://dx.doi.org/10.1787/9789264177338-en 